\title{
Effect of the Manufacturing Process on the Microbiota, Organoleptic Properties and Volatilome of Three Salmon-Based Products
}

\author{
Norman Wiernasz ${ }^{1,2}$, Frédérique Gigout ${ }^{1}$, Mireille Cardinal ${ }^{1}$, Josiane Cornet ${ }^{1}$, Jens Rohloff ${ }^{3}{ }^{D}$, \\ Philippe Courcoux ${ }^{4}$, Evelyne Vigneau ${ }^{4}$, Sigurlaug Skírnisdottír ${ }^{5}$, Delphine Passerini ${ }^{1} \mathbb{D}$, Marie-France Pilet ${ }^{2}$ \\ and Françoise Leroi ${ }^{1, *(D)}$
}

Citation: Wiernasz, N.; Gigout, F.; Cardinal, M.; Cornet, J.; Rohloff, J.; Courcoux, P.; Vigneau, E.; Skírnisdottír, S.; Passerini, D.; Pilet, M.-F.; et al. Effect of the Manufacturing Process on the Microbiota, Organoleptic Properties and Volatilome of Three

Salmon-Based Products. Foods 2021, 10, 2517. https://doi.org/10.3390/ foods10112517

Academic Editor: Concetta Messina

Received: 26 August 2021

Accepted: 11 October 2021

Published: 20 October 202

Publisher's Note: MDPI stays neutral with regard to jurisdictional claims in published maps and institutional affiliations.

Copyright: (c) 2021 by the authors. Licensee MDPI, Basel, Switzerland. This article is an open access article distributed under the terms and conditions of the Creative Commons Attribution (CC BY) license (https:// creativecommons.org/licenses/by/ $4.0 /)$.
1 IFREMER, BRM, EM3B Laboratory, F-44300 Nantes, France; norman.wiernasz@biofortis.fr (N.W.); frederique.gigout@ifremer.fr (F.G.); mireille.cardinal@ifremer.fr (M.C.); josiane.cornet1@sfr.fr (J.C.); delphine.passerini@ifremer.fr (D.P.)

2 UMR 1014, Secalim, INRAE, Oniris, 44307 Nantes, France; marie-france.pilet@inrae.fr

NTNU, Department of Biology, 7491 Trondheim, Norway; jens.rohloff@ntnu.no

4 StatSC, Oniris, INRAE, 44322 Nantes, France; philippe.courcoux@oniris-nantes.fr (P.C.); evelyne.vigneau@oniris-nantes.fr (E.V.)

5 Matis, Research and Innovation, Exploitation and Utilization of Genetic Resources, 101-155 Reykjavik, Iceland; sigurlaug@matis.is

* Correspondence: francoise.leroi@ifremer.fr

\begin{abstract}
Lightly preserved seafood products, such as cold-smoked fish and fish gravlax, are traditionally consumed in Europe and are of considerable economic importance. This work aimed to compare three products that were obtained from the same batch of fish: cold-smoked salmon (CSS) stored under vacuum packaging (VP) or a modified atmosphere packaging (MAP) and VP salmon dill gravlax (SG). Classical microbiological analyses and 16S rRNA metabarcoding, biochemical analyses (trimethylamine, total volatile basic nitrogen (TVBN), biogenic amines, $\mathrm{pH}$, volatile organic compounds (VOCs)) and sensory analyses (quantitative descriptive analysis) were performed on each product throughout their storage at a chilled temperature. The three products shared the same initial microbiota, which were mainly dominated by Photobacterium, Lactococcus and Lactobacillus genera. On day 28, the VP CSS ecosystem was mainly composed of Photobacterium and, to a lesser extent, Lactococcus and Lactobacillus genera, while Lactobacillus was dominant in the MAP CSS. The diversity was higher in the SG, which was mainly dominated by Enterobacteriaceae, Photobacterium, Lactobacillus and Lactococcus. Although the sensory spoilage was generally weak, gravlax was the most perishable product (slight increase in amine and acidic off-odors and flavors, fatty appearance, slight discoloration and drop in firmness), followed by the VP CSS, while the MAP CSS did not spoil. Spoilage was associated with an increase in the TVBN, biogenic amines and spoilage associated VOCs, such as decanal, nonanal, hexadecanal, benzaldehyde, benzeneacetaldehyde, ethanol, 3-methyl-1-butanol, 2,3-butanediol, 1-octen-3-ol, 2-butanone and 1-octen-3-one. This study showed that the processing and packaging conditions both had an effect on the microbial composition and the quality of the final product.
\end{abstract}

Keywords: cold-smoked salmon; gravlax; seafood; microbiology; metabarcoding; 16S rRNA gene; volatile organic compound; sensory analysis; quality

\section{Introduction}

Over the last decade, high-added-value seafood products, including smoked fish, gravlax and sea salads, have been gaining popularity in Europe and have dedicated refrigerated shelves in supermarkets. Cold-smoked salmon (CSS) is one of the best-selling products. The European production was estimated at 175,000 tons in 2019 for a trade 
value of 2.77 billion EUR, where the domestic demand mainly included France, the United Kingdom, Spain and Poland [1,2].

The smoking process is one of the oldest methods used to preserve fish. The process consists of three steps, namely, salting (dry salt or brine), drying and smoking sensu stricto. The smoking temperature varies from $22-25^{\circ} \mathrm{C}$ for CSS to $70{ }^{\circ} \mathrm{C}$ for hot-smoked salmon. The production of gravlax includes just the stages of salting, with a mixture of dried salt, sugar, spices and herbs, and drying. CSS and salmon gravlax (SG) are lightly processed products $(\mathrm{NaCl}<6 \%$ in the water phase, $\mathrm{pH}>5$, phenolic compounds $<20 \mathrm{mg} / \mathrm{kg}$ for CSS) that are usually stored at refrigerated temperatures under vacuum packaging (VP). Although not a common practice, a modified atmosphere (MAP) is sometimes used to store such products.

The light processing step does not eliminate microorganisms. Some of them can grow during storage, leading to the production of off-odors and flavors and a pasty texture. The sensory acceptability usually ranges between 2 to 4 weeks for gravlax and up to 6 weeks for CSS. It is generally admitted that the CSS initial microbiota is dominated by Gram-negative bacteria that are typically associated with fresh raw fish, such as Photobacterium, Shewanella, Vibrio and Yersinia. During storage, Gram-positive bacteria, especially lactic acid bacteria (LAB), such as Carnobacterium and Lactobacillus, become predominant with concentrations around $10^{7}-10^{9} \mathrm{CFU} / \mathrm{g}$. However, Enterobacteriaceae, Photobacterium and Brochothrix can also be present at sufficient levels to induce spoilage [3-13]. Although rarely quantified, yeasts are found throughout storage as subdominant microbiota $\left(10^{4} \mathrm{CFU} / \mathrm{g}\right)$ [3]. In SG and trout gravlax, Enterobacteriaceae dominate the ecosystem but LAB and to a lesser extent Brochothrix are also present [14-16].

Recently, new culture-independent methods, such as $16 \mathrm{~S}$ rRNA gene Illumina metabarcoding or 4-5-4 pyrosequencing, were used to obtain a full and clear picture of the microbial ecosystem composition and dynamics in foods. To date, only three studies considered VP CSS and involved twenty-two batches from different smokehouses and salmon origins analyzed throughout the storage [17-19]. A core microbiota between samples could clearly be found, even if some variation was observed. The initial microbiota was generally dominated by Photobacterium phosphoreum/kishitanii, Aliivibrio sp., Lactobacillus sakei, Brochothrix thermosphacta and, to a lesser extent, a few LAB, such as Leuconostoc gasicomitatum, Lactococcus piscium, Carnobacterium divergens and Carnobacterium maltaromaticum. The storage conditions exerted strong selective pressure on the initial microbiota and, at the spoiling date, the composition was highly variable between samples. Some batches were dominated by Staphylococcus equorum and LAB (Lactobacillus curvatus, Lactococcus lactis, C. divergens, C. maltaromaticum), while others were dominated by B. thermosphacta and LAB (C. maltaromaticum, Lactobacillus fuchuensis) or by P. phosphoreum/kishitanii alone. Enterobacteriaceae (Serratia proteamaculans and Hafnia alvei) were also detected in some samples, as well as Psychrobacter, Shewanella, Salinivibrio and unexpected Pantoea genera. No study was found on MAP CSS dices, and only one concerned a single batch of SG [16]. Its initial ecosystem was mainly composed of Photobacterium and Pseudomonas and many subdominant operational taxonomic units (OTU). During VP storage, the number of OTU decreased and Photobacterium, Serratia/Yersinia and Vibrio dominated the ecosystem, as well as Lactococcus, Carnobacterium, Lactobacillus and Aerococcus.

The objective of this study was to gain deeper knowledge of the quality of three salmon-based products, namely, salmon gravlax packed under VP (SG), CSS packed under VP (VP CSS) and CSS packed under MAP (MAP CSS), using classical and omics tool analysis. A polyphasic approach that included measures of the microbial ecosystem (cultural and metabarcoding), organoleptic quality, biogenic amines, total volatile basic nitrogen (TVBN), $\mathrm{pH}$ and volatilome was used. A new statistical approach (ComDim) was tested to draw links between the heterogeneous data to better understand the spoilage. The impact of different manufacturing processes or storage conditions was also evaluated, as the three products were obtained from the same batch of raw salmon. 


\section{Material and Methods}

\subsection{Salmon Products, Raw Material Process and Storage}

Raw salmon fish (Salmo salar) were purchased in Norway and processed on the same industrial site in France. Whole gutted salmon were filleted and stored at $4{ }^{\circ} \mathrm{C}$ in France, 4 days after slaughter. Salmon dill gravlax (SG) and smoked salmon were all processed the next day.

Salmon gravlax: Fillets were cured with a mix of salt, sugar, black pepper and dill (internal recipe) over $14 \mathrm{~h}$ at $6{ }^{\circ} \mathrm{C}$. They were then rinsed, sliced and packed in blisters under vacuum as $120 \mathrm{~g}$ portions of 8 slices.

Smoked salmon: Fillets were dry salted over $10 \mathrm{~h}$ at $4{ }^{\circ} \mathrm{C}$. They were then rinsed and dried for $2.5 \mathrm{~h}$ at $23^{\circ} \mathrm{C}$. Fillets were cold smoked over $6 \mathrm{~h}$ at $23{ }^{\circ} \mathrm{C}$ and left in a maturation chamber for 2 days at temperatures of $0-4{ }^{\circ} \mathrm{C}$. Matured fillets were sliced and vacuum packed as $150 \mathrm{~g}$ portions of 5 slices for smoked salmon under vacuum (VP CSS). For smoked salmon under a modified atmosphere (MAP CSS), the fillets were cut into cubes and packed under a modified atmosphere $\left(40 \% \mathrm{CO}_{2} / 60 \% \mathrm{~N}_{2}\right)$ as a $500 \mathrm{~g}$ portion.

Immediately after packaging, the products were transported to the laboratory under refrigerated conditions.

\subsection{Sampling Dates and Type of Analyses}

The commercial best before date for MAP CSS and SG was 28 days and 35 days for VP CSS. However, to push spoilage through extended storage, the MAP CSS and SG were stored for 35 days and the VP CSS for 49 days. All products were incubated at $4{ }^{\circ} \mathrm{C}$ for 1 week and then at $8{ }^{\circ} \mathrm{C}$ for the rest of the storage period. From T0, which corresponded to the first day of the experiment, and every 7 days, samples were withdrawn for microbial enumeration, biochemical analyses (trimethylamine (TMA), TVBN, biogenic amines, $\mathrm{pH}$, volatile organic compounds (VOCs) composition) and sensory analyses. Ecosystem monitoring through a metabarcoding approach was performed for the 3 products at T0 and after 14 and 28 days of storage. Except for the sensory assessment (see Section 2.5), all analyses were performed in triplicates.

\subsection{Classical Microbiological Analysis}

At each sampling date, $20 \mathrm{~g}$ of product were aseptically stomached (Stomacher 400 circulator, Seward Medical, London, UK) for $2 \mathrm{~min}$ with $80 \mathrm{~mL}$ of refrigerated sterile tryptone salt (TS) solution (Biokar Diagnostics, Beauvais, France) with 1\% Tween 80 (Grosseron, Saint-Herblain, France). After $30 \mathrm{~min}$ of revivification at room temperature, appropriate dilutions made in TS-Tween were poured or spread plated for enumeration of the total viable count (TVC) and total LAB, B. thermosphacta and Enterobacteriaceae counts, according to the conditions described by Wiernasz et al. [16].

\subsection{Metabarcoding of $16 S$ rRNA Gene}

Total bacterial DNA extraction and 16S rRNA sequencing: Bacterial DNA was extracted from the stomached solution according to the modified and optimized protocol with a MasterPure ${ }^{\mathrm{TM}}$ Gram Positive DNA purification kit (Epicentre, Illumina, Madison, WI, USA), as described by Wiernasz et al. [16]. The EMP primers set (515f/806r) from [20] was used to amplify the hypervariable V4 region of the bacterial 16S rRNA gene using polymerase chain reaction (PCR). Amplification and data treatment were performed as described by Wiernasz et al. [16].

Bioinformatics processing of the data: The bioinformatic processing of the data was done as described by Wiernasz et al. [16]. Briefly, FastQC [21] was applied on demultiplexed reads (around $300 \mathrm{pb}$ ) to check their quality. Reads R1 were trimmed after $280 \mathrm{pb}$ and reads $\mathrm{R} 2$ after $230 \mathrm{pb}$ with FASTX-trimmer from the FASTX-Toolkit [22]. Reads were then processed with the FROGS pipeline [23] using Flash [24] with 10\% mismatches, Cutadapt [25] and clustering with Swarm [26] according to Escudié et al. [23] recommendations. Clusters were then filtered regarding their abundance and occurrence by representing a minimum 
of $0.005 \%$ of all sequences and being present in at least 3 samples. Clusters affiliation was performed with blastn+ [27] against $16 \mathrm{~S}$ Silva database version 123 [28], and the OTU were filtered depending on the identity and coverage value of $100 \%$.

Downstream analyses were performed on rarified counts with $R$ version 3.4.4 [29] under the RStudio environment version 1.1.442 [30]. For the metabarcoding data, alpha and beta diversity analyses were performed using the R packages Phyloseq [31] and vegan version 2.5.7 [32]. For the beta diversity, a multidimensional scaling (MDS) analysis was conducted based on the samples' dissimilarity matrix, which was calculated using the BrayCurtis distance. The R package DESeq2 [33] was used to perform the differential abundance analysis on samples raw counts that were normalized following an rlog transformation $\left(\log _{2}(x+1)\right)$. All graphical visualizations were performed with the R package ggplot2 [34].

Fastq file availability: The raw fastq files were deposited on Ifremer's Sextant database and are accessible through the following DOI number: https:/ / doi.org/10.12770/1edc8 4cf-f3ef-47be-a096-e820b3806aec (accessed on 16 October 2018).

\subsection{Sensory Analysis}

At each sampling date, portions of the SG, VP CSS and MAP CSS were collected and kept frozen at $-80^{\circ} \mathrm{C}$ until analysis. For each product, a conventional sensory profiling test was conducted according to ISO 13299 [35]. The sensory evaluation was performed using an internal trained panel of 17 judges that were experienced in seafood, especially in salmon products $[10,36]$. During the sessions, the panelists were asked to assess the global spoilage based on aspect and off-odors perception. Then, the products were described according to a list of relevant sensory descriptors for odor (fatty fish, acid, amine, smoke and dill), appearance (fatty and orange color), texture (greasy film, firm, melting and pasty texture) and flavor (acid, salty, amine, fish, smoked, sweet and dill). Both the global spoilage and descriptors were scored depending on their intensity on a continuous scale from 0 (low intensity) up to 10 (high intensity). A product was considered strongly spoiled and unfit for consumption when the global spoilage level exceeded a threshold value of 6 .

The day before the sensory evaluation, samples were thawed overnight at $4{ }^{\circ} \mathrm{C}$. Sessions were performed in individual partitioned booths, as described in the procedure NF V-09-105 [37] and equipped with a computerized system (Fizz, Biosystèmes, Couternon, France). Each panelist received one slice of the SG and $15 \mathrm{~g}$ of MAP CSS dices, where both were presented in a covered plastic container. For the VP CSS, a half slice (around $15 \mathrm{~g}$ ) was repacked and presented in aluminum foil. Samples were assigned with 3-digit numbers and randomized regarding the order of presentation for each panelist. For each matrix, odor and appearance were assessed for all sampling dates, while flavor and texture were assessed on 3 dates: days 1, 21 and 28 for the SG; days 1, 21 and 35 for the MAP CSS; and days 1,28 and 35 for the VP CSS.

Normalized principal component analyses (PCAs) were performed on the sensory descriptors' mean scores using the R package ggfortify [38]. In addition, a two-way analysis of variance (ANOVA) was applied to the panelists' descriptor scores using products (with time) and panelists as independent factors. Significant differences between means were determined using Duncan's multiple range test $(p$-value $<0.05)$ (Fizz software, Biosystèmes, Couternon, France).

\subsection{Biochemical Analysis}

\subsubsection{Physicochemical Parameters}

The TVBN and TMA were quantified at each sampling date from $80 \mathrm{~g}$ of minced product according to the Conway microdiffusion method [39]. The $\mathrm{pH}$ value was measured directly after the microbiological analysis in the stomached solution with a $\mathrm{pH}$ meter (Mettler Toledo AG, Schwerzenbach, Switzerland). 


\subsubsection{Biogenic Amines Measurement}

Ten milliliters of the stomached solution (see Section 2.3) was mixed with $5 \mathrm{~mL}$ of a trichloroacetic acid solution at $12 \%$ (Panreac, Darmstadt, Germany). The samples were kept frozen at $-20{ }^{\circ} \mathrm{C}$ until analysis. Eight biogenic amines (tryptamine, 2-phenylethylamine, putrescine, cadaverine, histamine, tyramine, spermidine, spermine) were quantified using high-pressure liquid chromatography (HPLC) following Wiernasz et al.'s [40] methodology.

2.6.3. Headspace-Solid-Phase Microextraction (HS-SPME) and Gas

Chromatography/Mass Spectrometry (GC/MS) Analysis of the Volatilome

For each sampling date for the 3 products, portions of $20 \mathrm{~g}$ were withdrawn and stocked under VP at $-40{ }^{\circ} \mathrm{C}$. Eight salmon flesh cylinders were sampled across the frozen product using a pre-cooled metal cork borer and immediately pooled to make up $1 \mathrm{~g}$ of an analysis sample. Samples were kept frozen in $4 \mathrm{~mL}$ vials with a screw cap and PTFE/silicone septum at $-40{ }^{\circ} \mathrm{C}$ prior to extraction and analysis. For each sample (time point and treatment), 3 independent analysis samples (triplicate) were prepared. Prior to the volatile extraction, a $30 \% w / v ~ N a C l$ solution $\left(\mathrm{H}_{2} \mathrm{O}\right)$ was added to the sample, which was finally minced using a high-speed homogenizer. HS-SPME was applied for the extraction of VOCs using a manual SPME holder with a PDMS/DVB-coated $65 \mu \mathrm{m}$ fiber (Supelco Inc., Bellefonte, PA, USA). Prior to the extraction, the SPME fiber was conditioned in the injection port of the GC according to the instructions provided by the supplier. The SPME fiber was exposed to the atmosphere in the closed sample vial for 30 min while keeping the vial in an isothermal condition at $50^{\circ} \mathrm{C}$ in a water bath. Samples were constantly agitated using a magnetic stirrer during extraction.

An Agilent 6890/5975 GC/MS (Agilent Technologies Inc., Palo Alto, CA, USA) was used for all analyses. Analytes absorbed on the SPME fiber were desorbed in the injection port for 3 min under splitless conditions. GC separations were carried out using an apolar HP-5MS capillary column $(30 \mathrm{~m} \times 0.25 \mathrm{~mm}$ and film thickness $0.25 \mu \mathrm{m})$. The injection temperature was $220^{\circ} \mathrm{C}$ and the interface was set to $220^{\circ} \mathrm{C}$. The carrier gas was He at a constant flow rate of $1 \mathrm{~mL} / \mathrm{min}$. The GC temperature was ramped from 40 to $211^{\circ} \mathrm{C}$ at a rate of $4.5^{\circ} \mathrm{C} / \mathrm{min}$, then raised at a rate of $50{ }^{\circ} \mathrm{C} / \mathrm{min}$ and finally held at $220^{\circ} \mathrm{C}$ (total run time: $40 \mathrm{~min}$ ). The MS source was adjusted to $230^{\circ} \mathrm{C}$ and a mass range of $\mathrm{m} / z$ 35-350 was recorded. Mass spectra were acquired in electron impact ionization (EI) mode at $70 \mathrm{eV}$.

GC/MS chromatograms were visualized using the following GC/MS software packages: Agilent ChemStation software (Agilent Technologies, Waldbronn, Germany), AMDIS software (version 2.71; National Institute of Standards and Technology, Boulder, CO, USA) and the open-source program OpenChrom Community Edition Alder (version 1.2.0) (Lablicate GmbH, Hamburg, Germany; https:/ /lablicate.com/platform/openchrom)(accessed on 10 August 2021).

Tentative identification of compounds was carried out using (a) MS libraries, such as NIST05 spectral library (National Institute of Standards and Technology, Gaithersburgh, MD), the NIST Chemistry WebBook (https: / / webbook.nist.gov / chemistry)(accessed on 10 August 2021) and a customized in-house MS library of VOCs; in combination with (b) linear retention indices (LRI), based on a homologous series of even-numbered n-alkanes (C8 to C24); and (c) LRIs found in the literature and the NIST Chemistry WebBook. GC/MS data integration, normalization (total signal) and alignment were carried out using the Metalign software (RIKILT WUR, Wageningen, The Netherlands). The detected analytes concentrations were quantitatively estimated based on an internal standard (BHT) and expressed as micrograms per kilogram.

Multivariate analyses on the VOCs composition were performed using hierarchical clustering analysis (HCA) coupled with a heatmap on concentrations divided by the median and $\log _{2}$-transformed. The heatmap HCA was carried out with the R package gplots [41] using the Ward clustering method based on Euclidean distance. 


\subsection{Multiblock Data Integration}

The fusion of six blocks of information, i.e., the data matrices related to the metabarcoding, sensory characteristics, VOCs, microbial enumeration, biogenic amines and TVBN, was undertaken. For each type of product, observations were available at 3 sampling dates (T0, T14 and T28) in 3 independent replicates. In the case of sensory analysis, only one observation was available (see Section 2.5) and duplicated. The microbial ecosystem through metabarcoding data was represented using the two dimensions of an MDS analysis (see Section 2.4). Among various approaches proposed for multiblock data analysis, the ComDim method was considered [42,43]. ComDim analysis stipulates that the various blocks share the same underlying common components but that these components may be differentially weighted. The specific weight, or salience, of each block on each common dimension was iteratively optimized during the algorithm. They highlighted the importance of the various blocks for the determination of the common dimensions.

\section{Results}

\subsection{Microbial Analysis}

For the three products, the TVC, total LAB, Enterobacteriaceae and B. thermosphacta growth kinetics are shown in Figure 1. Globally, each enumerated flora started to increase quickly after 7 days, which corresponded to the temperature shift from 4 to $8{ }^{\circ} \mathrm{C}$. The SG initial TVC count was higher than for MAP and VP CSS $(4.0 \pm 0.1,3.1 \pm 0.2$ and $<1.7$ (detection threshold) $\log$ CFU/g, respectively. Maximum TVC counts were reached after 21 days for SG and 35 days for VP and MAP CSS (approximately 7, 7 and 8 CFU/g, respectively).

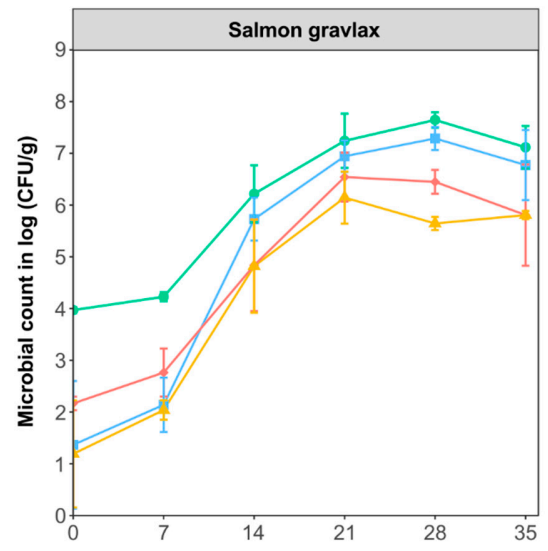

C

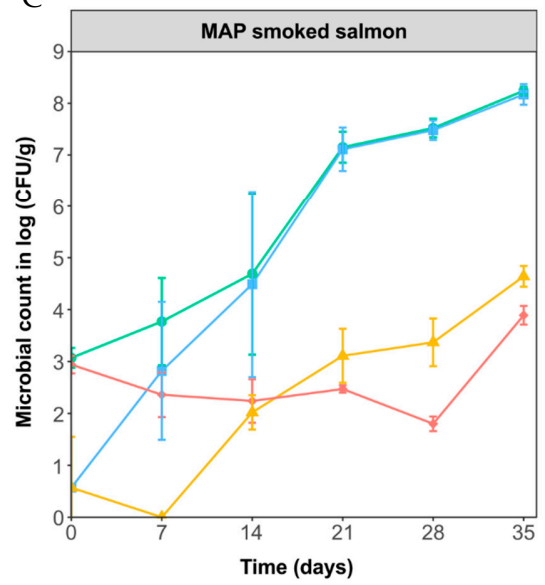

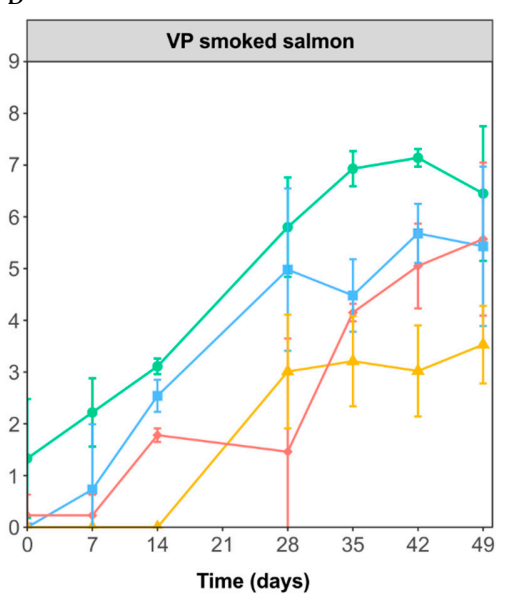

Figure 1. Microbial kinetics in the salmon gravlax (SG) (A), cold-smoked salmon packed under vacuum (VP CSS) (B) and cold-smoked salmon packed under modified atmosphere (MAP CSS) (C) during storage at $4{ }^{\circ} \mathrm{C}$ for 1 week and then at $8{ }^{\circ} \mathrm{C}$. Bars represent the standard deviation of the mean of 3 replicates. 
In the SG, the initial contamination could not be clearly defined as the TVC was 2-3 log $\mathrm{CFU} / \mathrm{g}$ higher than the selective counts. LAB, Enterobacteriaceae and B. thermosphacta, although in a minority at T0, quickly grew and reached $6.9 \pm 0.3,6.5 \pm 0.5$ and $6.1 \pm 0.5 \log$ $\mathrm{CFU} / \mathrm{g}$, respectively, at T21. However, TVC still remained a little higher than LAB $(+0.2 \mathrm{log}$ $\mathrm{CFU} / \mathrm{g}$ on average).

MAP CSS microbiota was dominated by LAB after 14 days of storage (LAB count equal to TVC and 3-4 log CFU/g higher than the other counts). The Enterobacteriaceae that were initially present $(2.9 \pm 0.2 \log \mathrm{CFU} / \mathrm{g})$ did not grow in the product. B. thermosphacta, which were not detected until 7 days, increased slowly to reach a maximum of $4.6 \pm 0.2 \log$ $\mathrm{CFU} / \mathrm{g}$ after 35 days of storage.

The initial contamination of the VP CSS was lower than in the other products and remained so until 28 days. After 35 days, the maximum count was reached $(6.9 \pm 0.3 \mathrm{CFU} / \mathrm{g})$ and was similar to the SG, but differed in composition. Indeed, LAB, Enterobacteriaceae and $B$. thermosphacta grew in the product but they never dominated. Their final concentrations were always 2 to $4 \log \mathrm{CFU} / \mathrm{g}$ lower than the TVC $(4.5 \pm 0.7,4.1 \pm 0.2$ and $3.2 \pm 0.9 \log \mathrm{CFU} / \mathrm{g}$, respectively, after 35 days).

For all sampling dates, an important variability in microbial counts was observed independent of the microbial flora considered, in particular, in the case of the VP CSS. Fillets were cut lengthwise and slices were gradually packed, resulting in a plastic blister containing only slices from the head, belly or tail part of the fish. The heterogeneous thickness and fat content may therefore explain the variability within triplicates.

\subsection{Ecosystem Monitoring through Metabarcoding}

A total of $3,977,403$ raw reads were obtained after the Illumina sequencing. A total of 1,746,144 reads passed through the FROGS pipeline for an average of 63,270 reads per sample. The number of sequences per sample ranged from 35,626 to 114,681 and the number of reads was normalized via rarefaction upon the lowest number of sequences per sample.

The SG, MAP CSS and VP CSS ecosystem compositions over time are shown in Figure 2. Regardless of the product and the three sampling dates, the microbial diversity was quite low. The richness in terms of the number of OTU per sample ranged between 27 and 56. The evenness of the OTU abundance distribution, calculated with the Shannon index, was between 1.1 and 1.5 for almost all samples. The values that were calculated for these two indexes showed an ecosystem that was mainly composed of a small number of highly dominant OTU that were affiliated with nine main bacterial genera: Photobacterium, Lactobacillus, Lactococcus, Serratia/Yersinia, Brochothrix, Carnobacterium, Vagococcus, Escherichia/Shigella and Cobetia, with a representative number of sequences that was superior to $0.5 \%$ of the total reads.

At the beginning of storage, the ecosystems were highly similar between the products, as the samples were closely clustered together on the MDS ordination plot shown in Figure 3. Photobacterium, Lactobacillus and Lactococcus were the dominant genera, accounting for about $95 \%$ of the microbial composition, with 50, 29-34 and 8-11\%, respectively (Figure 2). However, some differences were observed between the products. The SG initial microbial diversity was slightly higher than in the smoked products and remained higher until the end of storage. Indeed, twenty OTU that were specific to the gravlax were found, representing the fifteen following bacterial or archaea genera: Halorubrum, Shewanella, Bacillus, Weissella, Hafnia/Obesumbacterium, Acinetobacter, Brachybacterium, Duganella, Terribacillus, Spelaeicoccus, Halohasta, Staphylococcus, Comamonas, Sphingobacterium and Brevibacterium. Staphylococcus and Acinetobacter were the only shared genera between the three products (genera represented by several OTU). Genera such as Halohasta, Staphylococcus and Comamomas, which were specific to the SG microbial ecosystem as earlier reported were detected until 28 days of storage. Conversely, a differential abundance analysis using the DESeq2 R package revealed no statistical difference between the MAP and VP CSS microbial compositions at day 0 . 


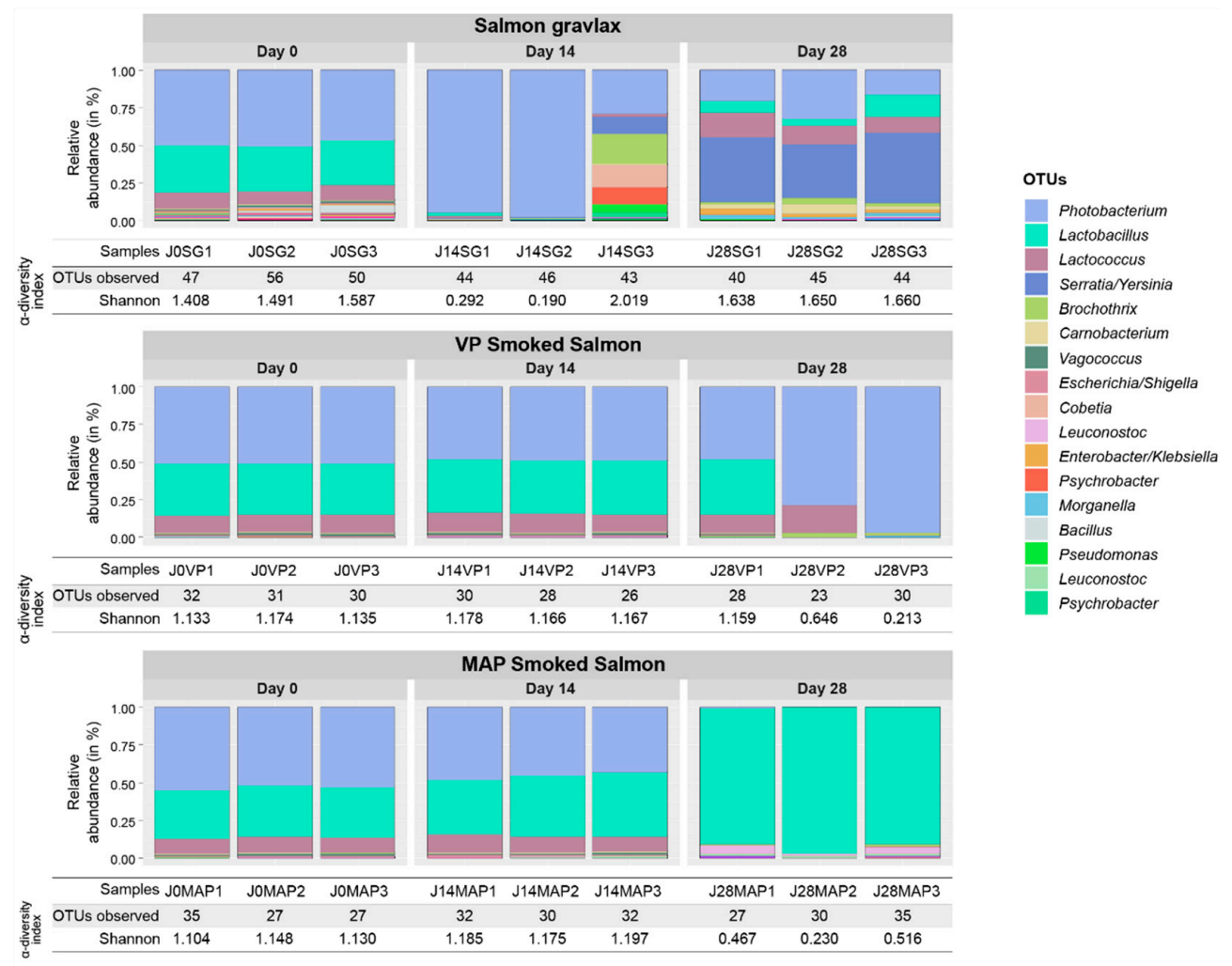

Figure 2. SG, MAP and VP CSS ecosystem relative compositions and $\alpha$-diversities. Only OTU with a number of sequences representing more than $0.1 \%$ of the total number of reads appear in the legend and are ordered from the most abundant to the least abundant. The sample nomenclature is structured as follows: (1) sampling date, (2) type of sample (MAP, VP or SG) and (3) replicate number. For each sampling date, the experiments were done in triplicates.

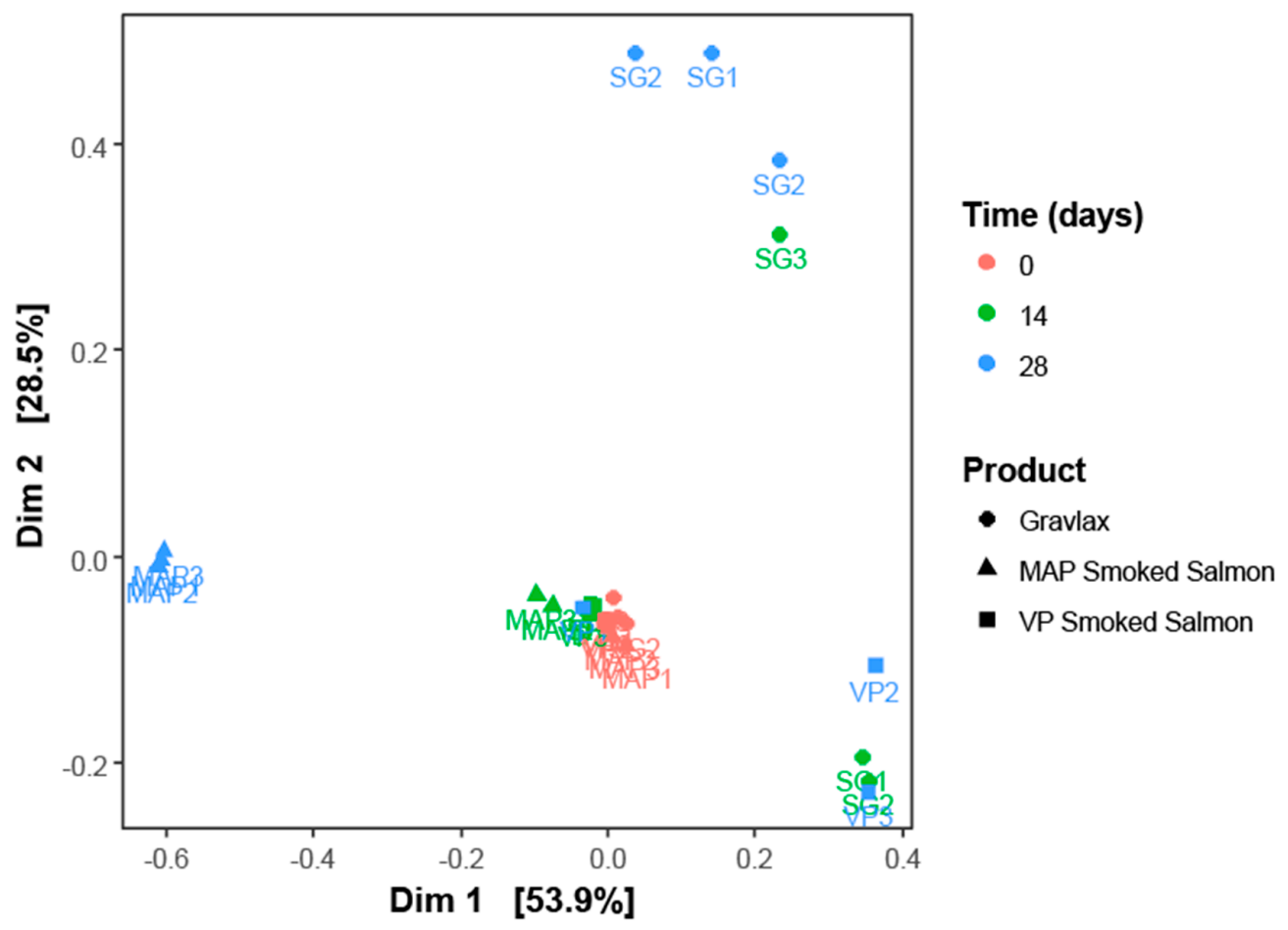

Figure 3. Multidimentional scaling representation of the SG, MAP and VP CSS samples microbial composition based on Bray-Curtis distances. The sample nomenclature is structured as follows: (1) the type of product (SG, MAP or VP) and (2) the replicate number. 
After 14 days of storage, the gravlax microbial ecosystem was the only one that diverged from the first sampling date, with a diversity that decreased significantly over time (ANOVA on the richness index, $p$-value $=0.045$ ). Except for the third biological replicate, the ecosystem composition was largely dominated by Photobacterium, whose relative abundance increased from 50 to $97.5 \%$ (Figure 2). In the third replicate, the microbial composition was more evenly distributed (highest Shannon index of 2.0) between seven genera: Photobacterium (29.0\%), Brochothrix (19.6\%), Cobetia (14.4\%), Psychrobacter (13.8\%), Serratia/Yersinia (11.9\%), Pseudomonas (5.6\%) and Lactococcus (1.7\%). In the case of the MAP and VP CSS, no statistical differences in terms of the OTU abundance were noticed between days 0 and 14 (Figures 2 and 3). Only a slight increase in abundance of 2 OTU belonging to Leuconostoc genera was observed for the MAP CSS. Moreover, in contrast to gravlax, the storage time showed no statistical effect on the ecosystem richness of the two smoked products (ANOVA, $p$-values of 0.854 and 0.196 ).

For the three products, the most important shift in the ecosystem took place between 14 and 28 days of storage (Figure 3). After 28 days, the SG ecosystem composition was more diverse than the two smoked products (Figure 2). The Photobacterium abundance dropped from 97.5 to $16.5-32.6 \%$ (variation between the triplicates) and Enterobacteriaceae increased to reach $35.1-46.9 \%$ for Serratia / Yersinia and 1.7-6.0\% for Enterobacter/Klebsiella. Some LAB genera, such as Lactobacillus, Carnobacterium and Lactococcus, which were weakly present at 14 days $(<1.5 \%)$, also increased after 28 days to reach $4.1-14.3,1.9-6.6$ and $10.8-16.4 \%$, respectively. For the MAP CSS, Photobacterium and Lactococcus disappeared $(<0.5 \%$ of abundance) in favor of Lactobacillus, which became the only dominant genus with more than $90 \%$ abundance and, to a lesser extent, Leuconostoc (1 to $5 \%$ abundance). Conversely, for VP CSS, despite the variability between replicates, the Photobacterium abundance increased to reach 78.4 and $96.8 \%$ in the second and third replicates, respectively, although Lactococcus and Lactobacillus remained present in some replicates.

\subsection{Salmon Based Products Sensory Evolution}

Until the end of the experiment, none of the products exceeded the sensory rejection threshold (global spoilage score $<6$ ). The spoilage was weak, with maximum scores of 3.9, 0.5 and 2.7 for the SG, MAP CSS and VP CSS, respectively, at the end of the experiment (data not shown). The PCA that was performed on the scores of profiling tests presented the main sensory characteristics for all samples (Figure 4). In Figure 4A (odor/color), the first axis ( $44.9 \%$ inertia) discriminated unspoiled from lightly spoiled samples, while the second (27.6\% inertia) discriminated unsmoked (SG) from smoked samples (MAP and VP CSS). In Figure 4B (flavor and texture), it was the opposite, with axis 1 (43.9\% inertia) discriminating SG from smoked products and axis 2 (31.7\% inertia) discriminating unspoiled from lightly spoiled samples.

The SG was considered lightly spoiled after 21 days, with the global spoilage score increasing from 0.2 on day 0 , to 3.0 and 3.9 on days 21 and 35, respectively (data not shown). The gravlax spoilage was defined by a significant decrease in the perception of the dill odor, orange color, fish flavor and melting texture (Figure 4). Salty flavor and amine and acid flavor and odor significantly increased (Duncan test with $p$-value $<0.05$ ). However, the acidic and amine odors that were associated with spoilage never exceeded scores of 2.0 and 2.6, respectively, after 35 days of storage.

The MAP CSS was never considered spoiled. During the 35 days of storage, it was characterized by a high perception of smoke odor and flavor, a stable fatty fish odor and flavor, a firm texture with moderate development of fatty droplets (greasy film) and the absence of spoilage notes, such as amine odor and flavor (score < 0.5) (Figure 4). The MAP CSS nevertheless showed some minor sensory changes during storage. Smoke odor, orange color and melting texture significantly decreased after the first week of storage, while the salty and acid flavor lightly increased after 35 days ( $p$-value $<0.05)$. A strong butter odor that was not figured in the sensory analysis criteria was also detected by panelists at the first sampling date and was never found later. 
A

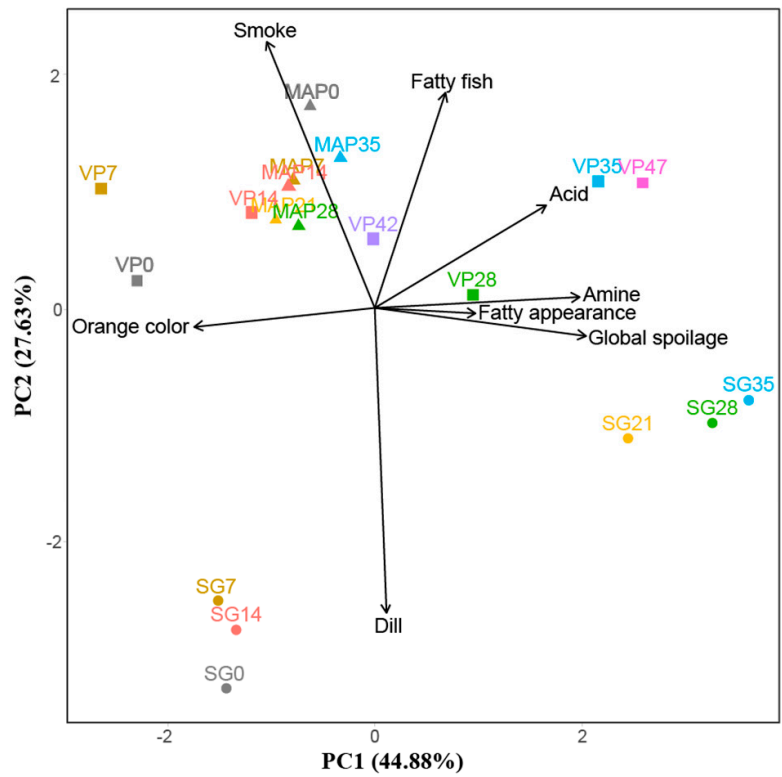

B

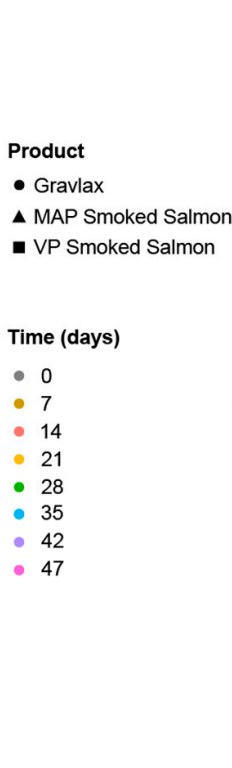

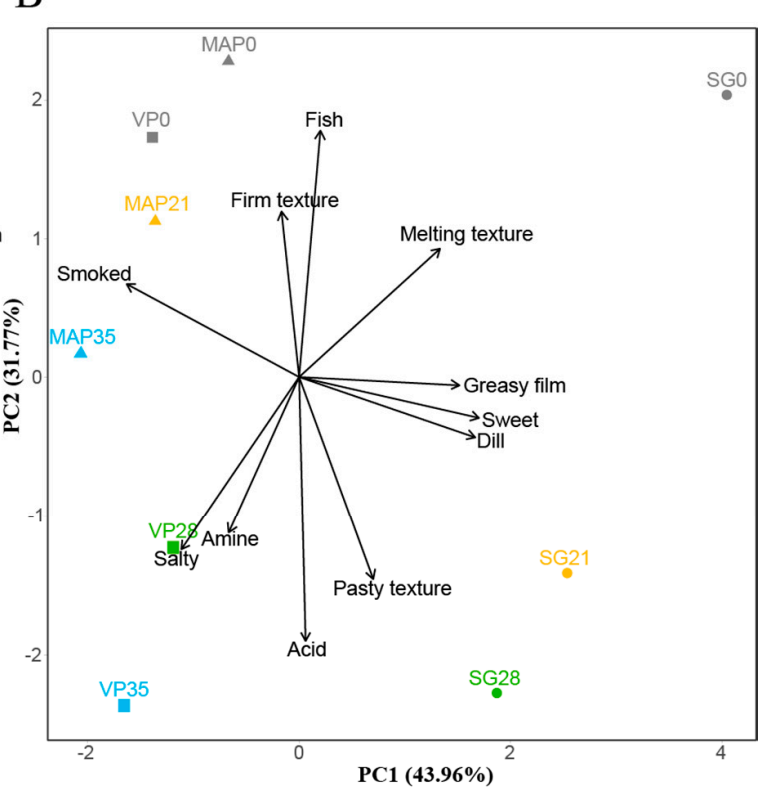

Figure 4. Normalized 2D principal component analysis (PCA) representation of the salmon gravlax (SG), smoked salmon stored under a modified atmosphere (MAP) and smoked salmon under vacuum package (VP) sensory evolutions based on visual and odor descriptors (A) and flavor and texture (B). Numbers associated with the sample name correspond to the sampling date in days.

The VP CSS was considered lightly spoiled after 35 days of storage with a score of 2.5. The smoke flavor and odor intensity were highly perceived by panelists at the beginning of storage and decreased at the end. As for the MAP CSS, the panelists also described the presence of a strong butter odor, which disappeared after the first week. The orange color and the firmness of the product also decreased significantly after 28 days of storage. An amine odor and flavor and an acidic flavor started to increase after 28 days to reach $2.8,1.9$ and 3.9, respectively. The fatty aspect of the product also increased significantly after 14 days (from 2.9 to 5.2 after 49 days). Nevertheless, no significant difference during storage was found for the greasy film texture $(p$-value $=0.31)$. An increase in the pasty texture, although not significant $(p$-value $=0.08)$, was also observed after 28 days of storage.

\subsection{Chemical Analyses}

The $\mathrm{pHs}$ of the three products were almost identical and remained stable during the whole storage time, with values between 5.47 and 5.93 (Table 1). However, the SG initial $\mathrm{pH}(5.87 \pm 0.10)$ was slightly higher $(p$-value $<0.05)$ than the MAP and VP CSS initial pHs $(5.68 \pm 0.02$ and $5.63 \pm 0.03$, respectively). The initial TVBN contents were similar for the three products $(12.0 \pm 1.8$ to $14.5 \pm 1.6 \mathrm{mg}-\mathrm{N} / 100 \mathrm{~g}$ (Table 1). The TVBN concentration in the SG and VP CSS increased during storage and reached their maxima of $28.1 \pm 1.0 \mathrm{mg}-\mathrm{N} / 100 \mathrm{~g}$ at day 28 and $24.7 \pm 2.5 \mathrm{mg}-\mathrm{N} / 100 \mathrm{~g}$ at day 35 , respectively. No production of TVBN in the MAP CSS was observed until the end of the experiment. Regardless of the product, no TMA was detected during the storage.

\subsection{Biogenic Amines Content}

Tryptamine, 2-phenylethylamine, putrescine, spermidine and spermine were under the detection threshold in all samples. The concentrations of cadaverine, tyramine and histamine are presented in Table 1. High variability was observed within the triplicates.

Concentrations of the three biogenic amines in the SG started to increase between 7 and 14 days of storage and remained stable until 28 days within a range of $276 \pm 31$ to $404 \pm 79 \mathrm{mg} / \mathrm{kg}$ for cadaverine, $42 \pm 13$ to $65 \pm 61 \mathrm{mg} / \mathrm{kg}$ for tyramine and $56 \pm 7$ to 
$117 \pm 104 \mathrm{mg} / \mathrm{kg}$ for histamine. As for the TVBN content, a decrease in biogenic amines was observed after 35 days.

Table 1. $\mathrm{pH}$ evolution, TVBN (mg-N/100g) and biogenic amines (mg/kg) contents in the salmon gravlax (SG), vacuumpacked (VP) and modified atmosphere packed (MAP) CSS during storage at $4{ }^{\circ} \mathrm{C}$ for 1 week and then at $8{ }^{\circ} \mathrm{C}$.

\begin{tabular}{|c|c|c|c|c|c|c|c|c|}
\hline $\begin{array}{c}\text { Sampling } \\
\text { Date (days) }\end{array}$ & 0 & 7 & 14 & 21 & 28 & 35 & 42 & 49 \\
\hline \multicolumn{9}{|l|}{ SG } \\
\hline $\mathrm{pH}$ & $5.87 \pm 0.10$ & $5.93 \pm 0.02$ & $5.62 \pm 0.04$ & $5.81 \pm 0.03$ & $5.77 \pm 0.02$ & $5.84 \pm 0.02$ & - & - \\
\hline TVBN & $12.0 \pm 1.8$ & $15.1 \pm 0.9$ & $22.2 \pm 5.3$ & $24.9 \pm 4.9$ & $28.2 \pm 1.0$ & $23.1 \pm 1.3$ & - & - \\
\hline Cadaverine & $2.0 \pm 0.1$ & $6.0 \pm 3.6$ & $294.2 \pm 224.1$ & $275.8 \pm 30.6$ & $404.1 \pm 79.4$ & $73.5 \pm 58.2$ & - & - \\
\hline Tyramine & $2.0 \pm 0.1$ & $2.0 \pm 0.1$ & $65.3 \pm 60.9$ & $42.2 \pm 12.9$ & $63.5 \pm 15.3$ & $13.0 \pm 12.0$ & - & - \\
\hline Histamine & $0.7 \pm 0.6$ & $1.3 \pm 0.6$ & $116.8 \pm 104.3$ & $57.7 \pm 7$ & $77.3 \pm 24.0$ & $17.1 \pm 12.7$ & - & - \\
\hline \multicolumn{9}{|l|}{ MAP CSS } \\
\hline $\mathrm{pH}$ & $5.68 \pm 0.02$ & $5.81 \pm 0.01$ & $5.53 \pm 0.07$ & $5.70 \pm 0.02$ & $5.65 \pm 0.04$ & $5.63 \pm 0.02$ & - & - \\
\hline TVBN & $14.4 \pm 0.7$ & $14.6 \pm 1.0$ & $14.2 \pm 1.9$ & $14.8 \pm 1.0$ & $13.3 \pm 2.6$ & $16.8 \pm 2.1$ & - & - \\
\hline Cadaverine & $2.3 \pm 2.1$ & $4.7 \pm 0.6$ & $9.0 \pm 5.6$ & $6.7 \pm 2.0$ & $6.2 \pm 1.0$ & $4.4 \pm 0.4$ & - & - \\
\hline Tyramine & 0.0 & 0.0 & $3.3 \pm 3.1$ & $0.2 \pm 0.4$ & $0.3 \pm 0.5$ & $6.2 \pm 2.7$ & - & - \\
\hline Histamine & $3.7 \pm 3.2$ & $6.0 \pm 1.0$ & $8.0 \pm 2.0$ & $5.3 \pm 0.6$ & $5.5 \pm 1.5$ & $5.2 \pm 0.7$ & - & - \\
\hline \multicolumn{9}{|l|}{ VP CSS } \\
\hline $\begin{array}{l}\text { PH } \\
\text { TVBN }\end{array}$ & $\begin{array}{c}5.03 \pm 0.03 \\
14.5 \pm 1.6\end{array}$ & $\begin{array}{c}5.81 \pm 0.0 Z \\
17.1 \pm 1.3\end{array}$ & $\begin{array}{l}17.5 \pm 1.3 \\
17.504\end{array}$ & - & $\begin{array}{c}.64 \pm 0.07 \\
21.0 \pm 3.7\end{array}$ & $\begin{array}{l}3.16 \pm 0.01 \\
24.7 \pm 2.5\end{array}$ & $\begin{array}{l}2.60 \pm 0.05 \\
24.6 \pm 3.6\end{array}$ & $\begin{array}{c}5.27 \pm 0.013 \\
25.9 \pm 5.0\end{array}$ \\
\hline Cadaverine & $4.0 \pm 1.0$ & $4.0 \pm 0.1$ & $4.6 \pm 0.9$ & - & $153.4 \pm 160.5$ & $185.0 \pm 186.3$ & $185.3 \pm 281.7$ & $218.9 \pm 187.9$ \\
\hline Tyramine & 0.0 & 0.0 & 0.0 & - & $26.7 \pm 36.0$ & $37.8 \pm 43.9$ & $49.5 \pm 78.5$ & $38.8 \pm 33.7$ \\
\hline Histamine & $6.7 \pm 1.2$ & $5.7 \pm 0.6$ & $5.6 \pm 0.2$ & - & $33.4 \pm 29.6$ & $56.3 \pm 61.9$ & $10.8 \pm 6.0$ & $59.4 \pm 45.2$ \\
\hline
\end{tabular}

In the VP CSS, biogenic amines production started after 28 days and also remained more or less stable until day 49. Their respective range values were always lower than in the SG and ranged from $153 \pm 160$ to $219 \pm 188 \mathrm{mg} / \mathrm{kg}$ for cadaverine, $27 \pm 36$ to $49 \pm 78 \mathrm{mg} / \mathrm{kg}$ for tyramine and $11 \pm 6$ to $59 \pm 45 \mathrm{mg} / \mathrm{kg}$ for histamine. Although the mean concentration of histamine was lower than $100 \mathrm{mg} / \mathrm{kg}$ (European tolerated concentration in some fish species), some replicates exceeded this limit (SG at day 14, VP CSS at days 35 and 49; data not shown).

In the MAP CSS, no biogenic amine exceeded $10 \mathrm{mg} / \mathrm{kg}$ for the whole storage duration.

\subsection{VOCs Profile}

The evolution of the volatilome composition for each product was visualized with an HCA heatmap based on a $\log _{2}(n)$ ratio of the mean concentrations amended by the median value (Figures 5-7).

The SG volatilome composition showed the lowest complexity, with 59 compounds detected using SPME-GC/MS. Twenty-eight were identified as terpenes, which were probably related to the presence of the spices (black pepper, dill) used in the curing step, where their concentrations remained stable during the storage period. As the storage progressed, an increase in the concentrations of alcohols (ethanol, 3-methyl-1-butanol, 2,3butanediol, 1-octen-3-ol, phenylethyl alcohol), aldehydes (nonanal, (E,E)-2,4-decadienal), aromatic aldehydes (benzaldehyde, benzeneacetaldehyde), ketones (2-butanone, 1-octen-3one) and 1-pentadecene was visible (Figure 5). Conversely, the alkane concentrations of, e.g., undecane, dodecane, tridecane and tetradecane, decreased over time.

The MAP and VP CSS volatilome compositions were much more complex than in the gravlax, with 164 and 149 compounds detected, respectively. For both products, more than half of all compounds were identified as furan and aromatic compounds that were related to the smoking process.

In the case of the VP CSS, despite the heterogeneity between the samples, a trend emerged that was characterized by an increase in the concentration of some aldehydes (decanal, hexadecanal), aromatic aldehydes (benzaldehyde, benzeneacetaldehyde), phenylethyl alcohol and 3,4-dimethyl-2-hydroxycyclopent-2-en-1-one (Figure 6). An increase in the production of dimethylamine (at days 28 and 35) and ethanol (at days 35 and 
42) was also visible. A decrease in the concentrations of some furan and aromatic compounds was recorded, such as 2,4,6-trimethylphenol, furfural, acetylfuran, 3-methylfurfural, 5-methylfurfural and unidentified aromatic-5/19/20.

Despite the absence of spoilage, slight variations in the MAP CSS VOCs concentrations were observed during storage. An increase in tetradecanoic and hexadecanoic acid, ethanol (at days 21 and 28), decanal, hexadecanal (after 28 days), tridecane, unidentified alkane-1/2/3/5/6, 3-furanmethanol and dimethylamine (at days 7, 21 and 28) were found (Figure 7). Conversely, a decrease in the concentration over time was visible for 3 -furaldehyde, styrene, unidentified aromatic-5/11/20 and 2-methoxy-4-vinylphenol. As for the VP CSS, a decrease in the concentrations of furfural, 3-methylfurfural and 5methylfurfural was also found. Nonetheless, except for furan and the aromatic compounds, the concentrations were relatively low (Supplementary Table S2); consequently, the variations that were observed in the HCA heatmap representation were amplified by the median emendation and the ratio transformation in $\log _{2}(\mathrm{n})$.

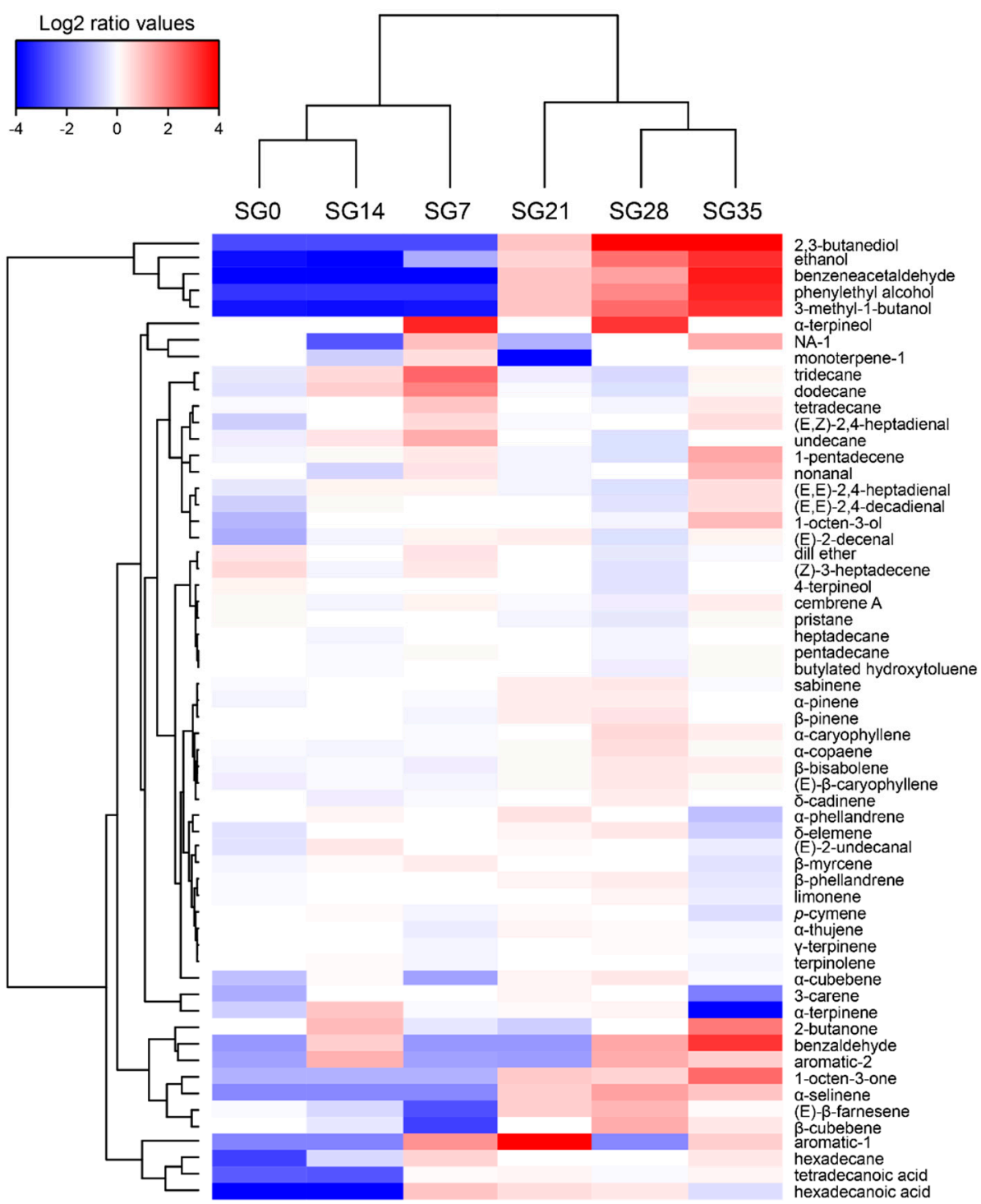

Figure 5. SG VOC hierarchical cluster analysis (HCA) heatmap based on the Euclidean distance calculated from $\log _{2}(n)$ transformation of the mean concentration $(n=3)$ amended by the median. The sampling time points are represented in columns (0 to 35 days), while the VOCs are depicted in rows. Blue colors indicate lower metabolite concentrations, while red colors show higher metabolite levels. See Supplementary Table S1. 


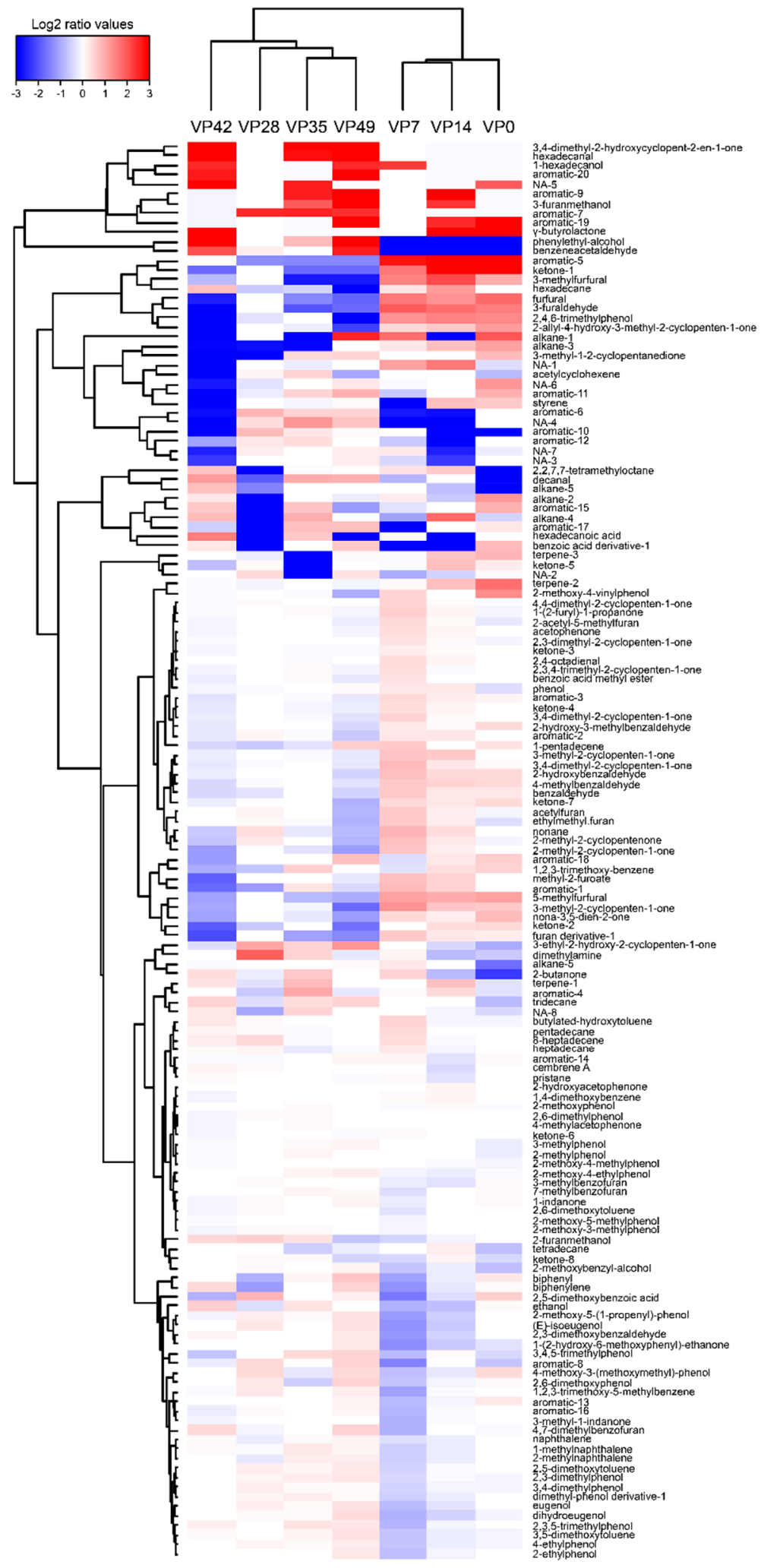

Figure 6. VP CSS VOC hierarchical cluster analysis (HCA) heatmap based on the Euclidean distance calculated from a $\log _{2}(\mathrm{n})$ transformation of the mean concentration $(n=3)$ amended by the median. The sampling time points are represented in columns (0 to 35 days), while the VOCs are depicted in rows. Blue colors indicate lower metabolite concentrations, while red colors show higher metabolite levels. See Supplementary Table S1. 


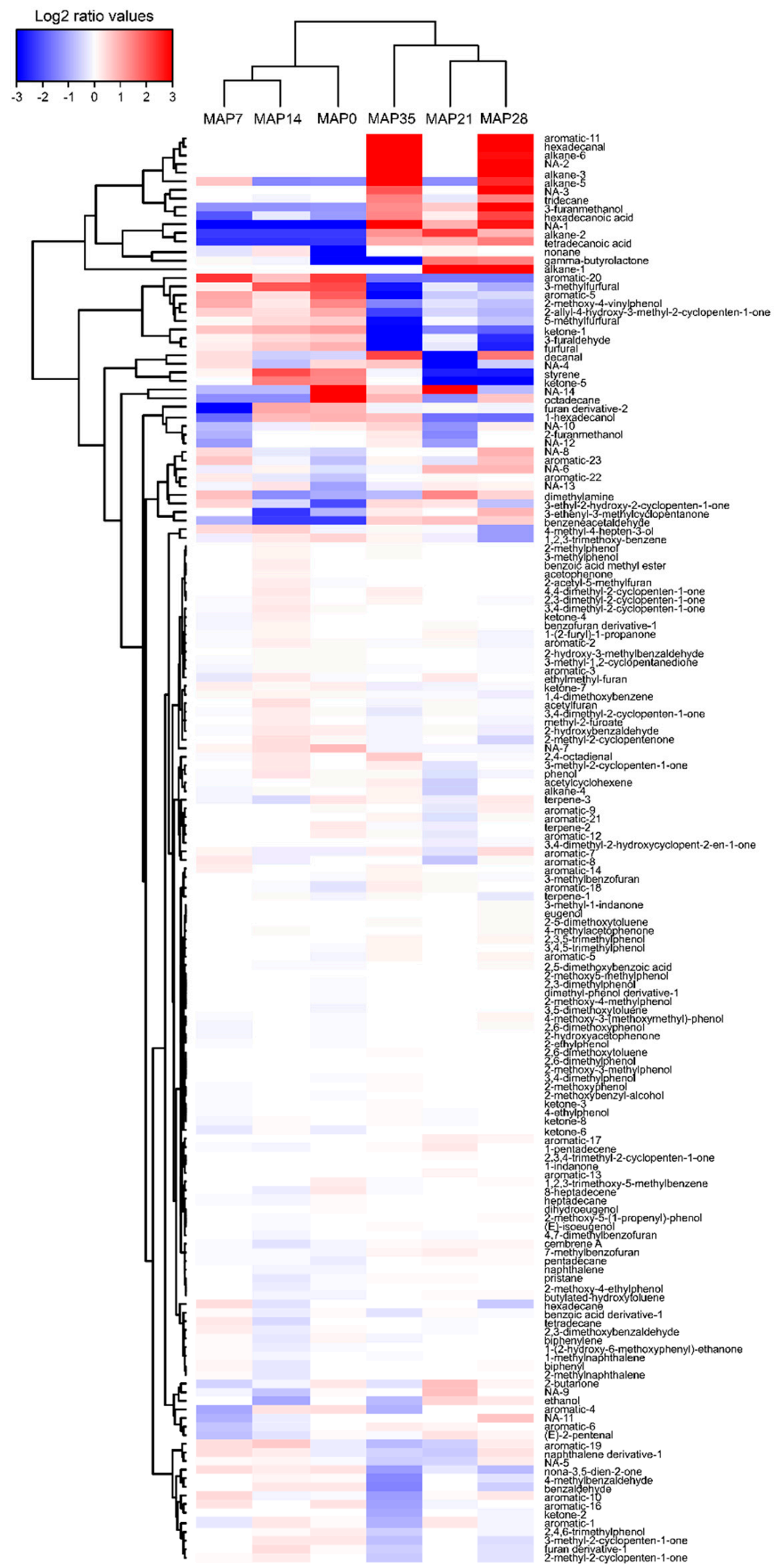

Figure 7. MAP CSS VOC hierarchical cluster analysis (HCA) heatmap based on the Euclidean distance calculated from a $\log _{2}(n)$ transformation of the mean concentration $(n=3)$ amended by the median. The sampling time points are represented in columns ( 0 to 35 days), while the VOCs are depicted in rows. Blue colors indicate lower metabolite concentrations, while red colors show higher metabolite levels. See Supplementary Table S1. 


\subsection{Integration of the Various Blocks of Data}

ComDim was performed using the six blocks of data: the microbial ecosystem data (metabarcoding) through the two MDS dimensions of the OTU abundance analysis ("OTU.dim", two variables), the sensory data ("SENSO", eight variables of odor/color), the $\log _{2}(\mathrm{n})$-transformed VOC data ("log2VOC", 17 compounds in common), the microbiological data ("MICROBIO", six variables), the biogenic amines ("BIOGAMI", six variables) and the TVBN measurements (one variable).

From Table 2, three dimensions were retained. The first dimension accounted for $45 \%$ of the total variation in the multiblock data set. For this dimension, TVBN had the highest specific weight, or salience (52\%), followed by the blocks BIOGAMI $(22 \%)$ and MICROBIO $(18 \%)$ (data not shown). The second dimension was specifically associated with the block OTUdim (salience of $91 \%$ ), whereas the third dimension accounted for both the $\log _{2} \mathrm{VOC}$ and SENSO blocks (saliences of 52 and $41 \%$, respectively).

Table 2. Percentage of the variability explained (\%expl) and cumulative percentage (cum\%expl) explained by the first common components defined using ComDim.

\begin{tabular}{ccc}
\hline & \%expl & cum\%expl \\
\hline Dim.1 & 45.56 & 45.56 \\
Dim. & 14.35 & 59.91 \\
Dim.3 & 11.15 & 71.06 \\
Dim.4 & 6.45 & 77.51 \\
Dim.5 & 4.15 & 81.66 \\
\hline
\end{tabular}

The score plots in dimensions 1 and 2, on the one hand, and 2 and 3, on the other hand, are shown in Figure 8A,B. The evolution of the products with the number of days of storage was reflected in different ways. For the SG at 28 days and, to a lesser extent, for the SG at 14 days or VP at 28 days, the increase in the TVBN (along the first dimension) was pronounced. By comparison, the MAP CSS did not show such a pattern at 28 days, but a modification in the microbial ecosystems was noticed, which was reflected by the second dimension. As stated in Section 3.2, the MAP ecosystem composition was characterized by a decrease in Photobacterium in favor of Lactobacillus over time, which was expressed along the second dimension of ComDim. Moreover, a detailed analysis of the OTU with this second dimension made it possible to highlight that the SG ecosystem at 28 days of storage could be associated with specific genera, such as Carnobacterium, Morganella and Bacillus. Finally, the third dimension of ComDim showed a common contribution of sensory and VOCs data, allowing for the description of SG salmon samples at 0 or 14 days of storage, which was not shown for the MAP and VP CCS. The correlation coefficients between the raw data and this third dimension highlighted the sensory odor "dill" as being specific toward SG at day 0, which was associated with VOCs, such as pristane, pentadecane, heptadecane and tridecane. A smoke odor was associated with benzaldehyde and butylate hydroxytoluene compounds. 
A

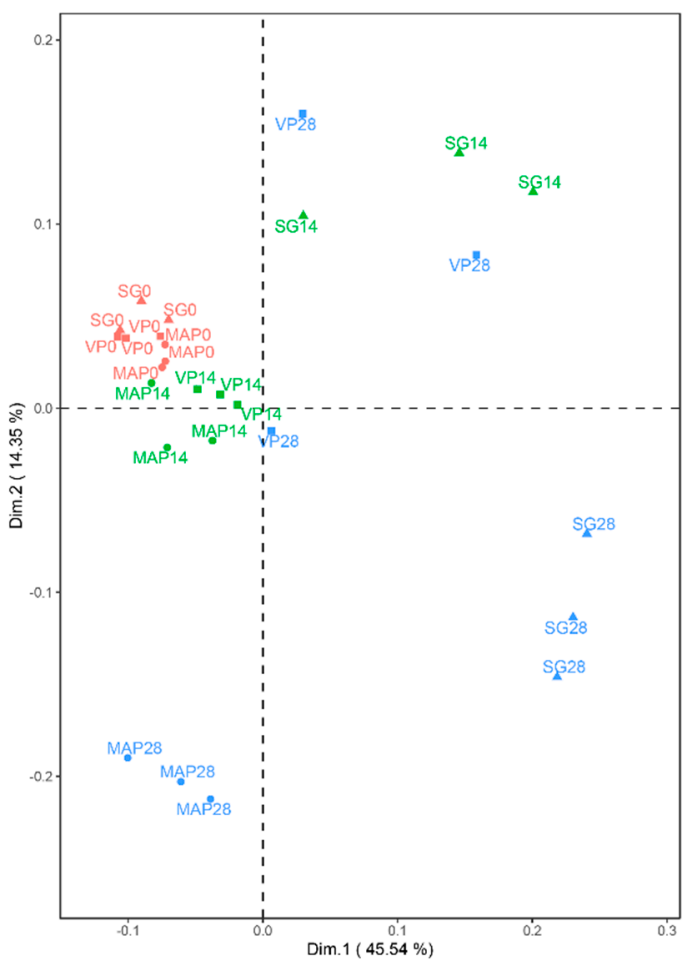

B

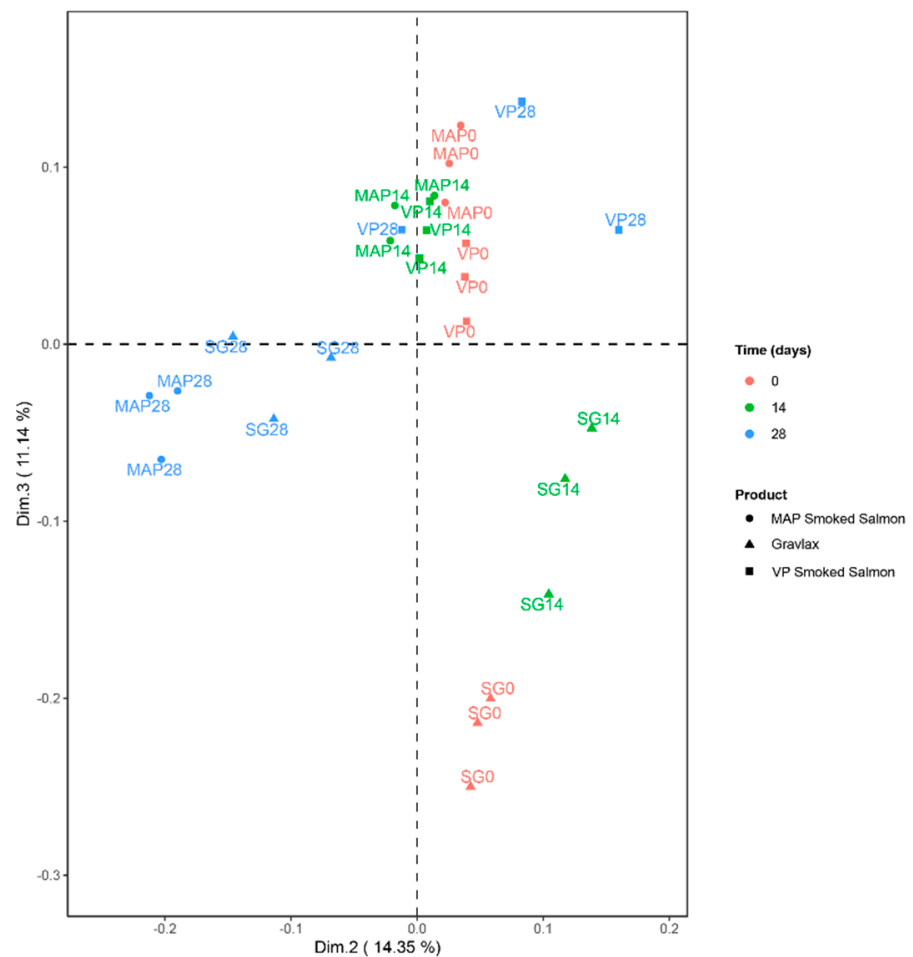

Figure 8. Multidimensional representation of the three products, namely, SG, MAP CSS and VP CSS, at three sampling time points using the various blocks of data collected by means of the ComDim method. (A) Projection of individuals in dimensions 1 and 2, (B) projection of individuals in dimensions 2 and 3. Numbers associated with the sample name correspond to the sampling date in days.

\section{Discussion}

The objective of this study was to gain deeper knowledge about the quality of three salmon-based products and to compare the effect of the manufacturing process on their microbial ecosystem, organoleptic properties and volatilome. After the packaging step, the TVC counts were 4.0, 3.0 and $<1.7 \mathrm{log}$ CFU/g for the SG, MAP CSS and VP CSS, respectively. Such initial bacterial loads are usually found in lightly preserved salmon products $[3-6,9,14,44]$ but may sometimes reach 5-6 log CFU/g depending on the raw material and smokehouse hygienic quality $[4,6,10]$. The difference within the product was more likely due to the smoking process rather than the salt concentration, which was lower in the less-contaminated product $(2.58 \pm 0.05,3.05 \pm 0.12$ and $2.17 \pm 0.28 \mathrm{NaCl} / 100 \mathrm{~g}$ flesh for the SG, MAP CSS and VP CSS, respectively). Phenolic compounds are known to possess antimicrobial activity [45] and are responsible for bacterial growth delay or inhibition in CSS [46-49]. In this study, the total phenolic compounds were much more concentrated in the MAP and VP CSS ( $28 \pm 1$ and $35 \pm 5 \mathrm{mg} / \mathrm{kg}$ of flesh, respectively) than what is usually found in CSS (often $<10 \mathrm{mg} / \mathrm{kg}$ ). The lower phenolic concentration in MAP CSS compared to VP CSS may explain the higher initial bacterial count in the MAP CSS. This may also be explained by the supplementary cutting step to obtain dices, which was probably responsible for the recontamination before packaging, especially by Enterobacteriaceae (Figure 1).

On day 0 , the three products' microbial ecosystems were relatively close in the proportions of Photobacterium, Lactobacillus and Lactococcus, accounting for about 50, 30 and $10 \%$ of the composition, respectively. Despite an overall compositional similarity, the SG ecosystem diversity was initially higher than the smoked products and remained so until 28 days. The diversity may be explained by the spices and herbs used for the SG preparation and the absence of selective pressure due to smoke. There were 20 OTU specific to 
the SG and belonged to the bacterial and archaeal kingdom. Among them, Shewanella (S. putrefaciens, S. vesiculosa, S. morhuae, S. baltica, S. frigidimarina), Hafnia (H. alvei), Weissella (W. confusa, W. viridescens, W. kandleri), Staphylococcus (S. equorum) and Bacillus are ubiquitous bacterial genera that were isolated from a wide variety of ecological niches, including seafood $[3,6,9,13,14,17-19,50-58]$. On the other hand, for some ecological niches, Duganella, Terribacillus, Spelaeicoccus, Comamonas, Sphingobacterium, Brevibacterium, Halorubrum and Halohasta are relatively unknown and not frequently described. Table 3 summarizes some ecological origins of these uncommon bacteria or archaea. Some were isolated from a specific ecological niche (e.g., Halohasta and Halorubrum in salt) but others are ubiquitous and can therefore be brought with the spices used for the SG preparation. Next-generation sequencing techniques are powerful tools for pinpointing minor microbial populations within ecosystems, which is information that is otherwise inaccessible using common cultural methods. For instance, Chaillou et al. [17] also detected Sphingobacterium sp. and Brachybacterium sp. in diced bacon and Comamonas sp. in cod and salmon fillets with pyrosequencing technology, although no isolate was collected.

For the three matrices, the most important shift in the microbial population occurred between 14 and 28 days, when the growth of different bacterial flora reached their stationary phase. After 28 days, in the SG, Enterobacteriaceae mostly dominated the ecosystem, with an OTU corresponding to the Serratia/Yersinia genera representing $35-47 \%$ of the total composition. In trout gravlax stored under VP at 3 and $8{ }^{\circ} \mathrm{C}$, Lyhs et al. [15] showed that $\mathrm{H}_{2} \mathrm{~S}$-producing bacteria (which include some Enterobacteriaceae) represented a major part of the spoilage microbial flora. Wiernasz et al. [16] also found Serratia/Yersinia in SG on days 14 and 21 with metabarcoding analysis. Smoke seemed to exert an additional selection pressure during storage as the OTU number was lower in the VP CSS and MAP CSS than in the SG. At the end of the storage, the microbial composition of the MAP CSS was only dominated by LAB, such as Lactobacillus ( $>90 \%$ ) and, to a lesser extent, Leuconostoc (4-6\%). These results were in accordance with those obtained with the cultural method, with the LAB count being identical to the TVC. In the VP CSS, depending on the biological replicate, Lactobacillus and Lactococcus were also detected in a high proportion (13 to 37\%). The VP and MAP of food commodities are known to favor LAB growth [13,59-61]. Lactobacillus and Lactococcus were the main LAB genera that were detected in the products. Many species of Lactobacillus (L. alimentarium, L. casei subsp. tolerans, L. coryneformis, L. curvatus, L. delbrueckii subsp. delbrueckii, L. farciminis, L. fuchuensis, L. homohiochii, L. malfermentans, L. plantarum, L. pentosus, L. brevis, L. sakei and L. sanfranciscensis) and Lactococcus (mainly L. piscium, but also L. lactis and L plantarum) are frequently isolated from seafood products [17,62-64]. Although the spoilage potential of LAB in seafood is strain-dependent, some species, such L. sakei, L. farciminis and L. fuchuensis, frequently induced off-odor in shrimp, raw salmon and CSS. Other species (L. alimentarius, L. piscium) generally do not affect the quality [18,63,65-67]. No sign of alteration was found in the MAP CSS, even after 35 days. This may have been due to the absence of such spoilage species. However, the relatively low concentration of $\mathrm{LAB}\left(10^{7} \mathrm{CFU} / \mathrm{g}\right)$ may also explain this result.

In the VP CSS, the Photobacterium relative abundance increased from day 14 to day 28 and was dominant, accounting for 78 to $97 \%$ of the microbial composition. Photobacterium is capable of anaerobic respiration via the use of TMA-oxide, which is often present in marine fish, as a final electron acceptor, making this bacterium able to grow under MAP and VP [50]. The final metabolite, namely, the TMA, is strongly malodorant and responsible for "amine" off-odors. Photobacterium was also found to be part of the dominant microbial flora of VP CSS [12,18]. However, caution must be taken with a metabarcoding approach as its detection might be largely overestimated due to the use of the 16S rRNA gene as a target. According to the rrnDB database [68], Photobacterium, especially P. phosphoreum, which is the main species encountered in seafood, possesses 15 copies of the $16 \mathrm{~S}$ rRNA gene in its genome, while the average copy number for the bacterial kingdom is only 4.8.

The three products' sensory qualities remained acceptable for the whole storage duration. Usually, lightly preserved seafood products are declared spoiled and unfit 
for consumption after 3 to 4 weeks for fish gravlax [14,15] and after 5 to 6 weeks for CSS [3-6,9,10], and their final bacterial load can reach 8 to $9 \log$ CFU/g [13]. In our study, the extended shelf-life might be explained by the low TVC count, which never exceeded 7-8 $\log \mathrm{CFU} / \mathrm{g}$, which was probably related to high salt and smoke concentrations. Weak spoilage, as well as acidic and amine off-odors and flavors, increased a bit during storage of the SG and VP CSS, as well as fatty droplets at the products' surfaces, while the perception of the freshness-related odor, flavor and color, such as fresh fish, dill, smoke and orange, decreased slightly over time. Such spoilage sensory characteristics are commonly described for lightly preserved salmon products $[5,6,10,69]$. They can be induced by the presence of specific spoiling bacteria, such as B. thermosphacta, P. phosphoreum and S. liquefaciens [65]. The fact that spoilage was classified in the following order: SG > VP CSS > MAP CSS might be explained by the microbial diversity and higher presence of Gram-negative bacteria, such as P. phosphoreum and Enterobacteriaceae.

Resulting from enzymatic reactions and microbial degradation, the TVBN $[4,10,70]$ and biogenic amines $[51,71,72]$ can be indicators of spoilage in seafood. In the SG and VP CSS, the TVBN, tyramine, cadaverine and histamine production started when the TVC count reached $6 \log$ CFU/g after 14 and 28 days for the SG and VP CSS, respectively. Although not known to be a fish with a high histidine content, some replicates of each product exceeded $100 \mathrm{mg} / \mathrm{kg}$ of histamine, which is the EU regulatory tolerated concentration in some fish species (not including salmon) [73]. This may have been related to the presence of Photobacterium sp. Some authors have found equivalent or even higher concentrations for cadaverine, tyramine and histamine in spoiled CSS [51,69]. No production of biogenic amines was found in MAP CSS, despite a microbial load of $8.2 \pm 0.1 \log$ CFU/g. In this product, the microbial ecosystem was mainly dominated by Lactobacillus, which are not strong biogenic amine producers in seafood [74,75]. In the same way, no TVBN production was found in the MAP CSS. In the SG and VP CSS, the TVBN increased slightly over time but did not exceed the European regulatory limit of $35 \mathrm{mg}-\mathrm{N} / 100 \mathrm{~g}$ for unprocessed salmon [73].

The VOCs composition of the three products, especially the MAP CSS, did not change much over time. However, increases in the concentrations of alcohols (ethanol, 3-methyl1-butanol, 2,3-butanediol, 1-octen-3-ol, phenylethyl alcohol), aldehydes (nonanal, (E,E)2,4-decadienal, hexadecanal benzaldehyde, benzeneacetaldehyde), ketones (2-butanone, 1-octen-3-one) and dimethylamine (VP CSS only) were observed. Aldehydes, amines, ketones, alcohols and organic acids production result mostly from microbial activity and their concentration increased concomitantly with the deterioration of the seafood organoleptic properties [8,76-79]. For instance, aldehydes resulting from lipids oxidation by microorganisms are good indicators for food degradation and actively participate in the characteristic rancid, cooked potatoes, fatty, floral, fruity and grassy odors of spoiled fish $[8,78,79]$. P. phosporeum, B. thermosphacta and S. liquefaciens, which are common seafood spoilers, induced the production of many spoilage-related volatile compounds, such as benzene ethanol, 2-methylpropanol, 3-methyl-2-butanol, 2,3-methyl-1-butanol, 1-propanol, 1-penten-3-ol, acetaldehyde, 2,3-methyl-1-butanal, pentanal, 2-methyl-1-propanal, benzaldehyde, benzeneacetaldehyde, 2,3-butanedione, 2-propanone, 3-pentanone, 3-methyl2-butanone, 3-hydroxybutanone (acetoin), acetic acid and ethyl acetate, when added in cooked and peeled shrimp and raw and cold-smoked salmon [36,80,81]. Interestingly, an important decrease in furanic aldehydes (furfural, 3-methylfurfural, 5-methylfurfural and 3-furaldehyde) was observed during the storage of the two smoked products. Many furanic aldehydes are found in smoked fish $[8,77,79,82,83]$. Most of them are found in the smoke but can also be generated through Maillard and Strecker reactions between the wood smoke and the fish flesh during the smoking process [78]. Several bacteria, including species from Pseudomonas, Acinetobacter and Serratia genera, are able to metabolize furfural and hydroxymethylfurfural compounds into furfuryl alcohols (2-furanmethanol and 3-furanmethanol) [84]. These two alcohols were detected in the MAP and VP CSS and slightly increased over time. 
Table 3. Ecological origin of uncommon genera that were only detected using the metabarcoding approach in salmon dill gravlax.

\begin{tabular}{ccc}
\hline Genus & Ecological Origin & References \\
\hline Bacteria & Salt-fermented seafood, lake sediment, soil, seawater, & \\
animal feces & {$[85-88]$} \\
Brachybacterium & Soil, plant roots, water & {$[89-91]$} \\
Terribacillus & Soil, salted lake sediment, plant material & {$[92-94]$} \\
Spelaicoccus & Soil & {$[95]$} \\
Brevibacterium & Soil, seawater, feces, compost, plant material, milk, & cheese, poultry, CSS \\
Comamonas & Freshwater, plant, compost, soil, fish gut & {$[96-100]$} \\
Sphingobacterium & Soil, permafrost, glacier, animal feces and gut, milk, & {$[101-105]$} \\
Archaea & compost, plant material, lichen, freshwater & {$[106-112]$} \\
Halorubrum & Salt-fermented seafood, rock salt, salted lake sediment, & \\
Halohasta & solar saltern & {$[113-116]$} \\
\hline
\end{tabular}

The characterization of the product quality over the storage time involves the combination of a wide range of analyses giving heterogeneous sets of data requiring multivariate statistical analysis. In this study, the use of the multiblock analysis method ComDim allowed for characterizing the samples according to relationships existing between classical microbial analysis, microbiota, physico-chemical parameters, sensory analysis and VOCs. The main parameters that allowed for discriminating between samples were the TVBN and, to a lesser extent, the biogenic amines and microbial ecosystem. The SG on days 14 and 28 and the VP CSS on day 28 were mainly characterized by higher TVBN and biogenic amines contents. The MAP CSS on day 28 differed from the other samples mainly by its microbiological shift, with a decrease in Photobacterium and an increase in Lactobacillus, while some OTU were very specific to the SG. Sensory analysis and COV mainly discriminated samples at the early stage of storage according to the process (unsmoked from smoked products). The ComDim approach was used to illustrate the tools that could be used to integrate very heterogeneous data, especially those from metabarcoding, which is a relatively new technique. Such methods might be applied to larger sets of data that are derived from a larger number of samples showing less processing variability.

\section{Conclusions}

This study showed that the process and packaging conditions both had an effect on the microbial composition and the quality of the final product. Although the sensory spoilage was generally weak, gravlax was the most perishable product, followed by the VP CSS and MAP CSS. This result is in accordance with all the parameters measured in this study. The TVBN, cadaverine, tyramine and histamine were in higher concentrations in the SG, followed by the VP CSS and then the MAP CSS. The microbial diversity in gravlax was high, probably due to the spices and herb additions in the process and the absence of antimicrobial phenolic compounds. LAB aside, the most abundant genera that were identified using metabarcoding (Photobacterium, Serratia/Yersinia and Brochothrix) are known to be specific spoilage microorganisms in seafood. In the smoked product, after 28 days, the VP selected Photobacterium as the dominant flora but LAB, Enterobacteriaceae and Brochothrix were still present. The MAP selected only LAB (mainly Lactobacillus) as the dominant flora, which did not deteriorate the sensory quality.

Supplementary Materials: The following are available online at https://www.mdpi.com/article/10 .3390/foods10112517/s1. Table S1: OTU Table. Table S2: Volatile Organic Compounds Table.

Author Contributions: Conceptualization, F.L., M.-F.P., N.W. and D.P.; methodology and microbial analysis, N.W. and F.G.; sensory analysis, M.C. and J.C.; metabarcoding, N.W. and S.S., Metabarcoding- 
data treatment, N.W.; volatiles organics compounds (VOCs), J.R.; VOCs-data treatment, J.R. and N.W.; ComDim, E.V. and P.C.; writing-original draft preparation, N.W. with contributions from J.R. and E.V.; writing-review and editing, F.L. and M.-F.P.; supervision, F.L. and M.-F.P.; project administration, F.L.; funding acquisition, F.L. and M.-F.P. All authors have read and agreed to the published version of the manuscript.

Funding: This study was supported by a public grant from the French Agence Nationale de la Recherche within the context of the ERANET COFASP program (reference ANR-14-COFA-0001, project SAFEFISHDISH).

Acknowledgments: The authors thank Christine Chopin and Claire Donnay-Moreno for their kind technical assistance with the biogenic amines, TVBN and TMA analyses and Marc Jérôme for their help regarding the DNA extraction.

Conflicts of Interest: The authors declare no conflict of interest.

\section{References}

1. FranceAgriMer Consommation Des Produits de La Pêche et de l'aquaculture 2017. Available online: http:/ / www.franceagrimer. $\mathrm{fr} / \mathrm{fam} /$ content/download/52763/508694/file/STA-MER-CONSO\%202016-juil2017.pdf (accessed on 10 July 2018).

2. EUFOMA. The EU Fish Market. 2020 Edition. Available online: https://www.eumofa.eu/fr/the-eu-fish-market-2020-edition-isnow-online (accessed on 25 August 2021).

3. Leroi, F.; Joffraud, J.-J.; Chevalier, F.; Cardinal, M. Study of the Microbial Ecology of Cold-Smoked Salmon during Storage at $8{ }^{\circ}$ C. Int. J. Food Microbiol. 1998, 39, 111-121. [CrossRef]

4. Leroi, F.; Joffraud, J.J.; Chevalier, F.; Cardinal, M. Research of Quality Indices for Cold-Smoked Salmon Using a Stepwise Multiple Regression of Microbiological Counts and Physico-Chemical Parameters. J. Appl. Microbiol. 2001, 90, 578-587. [CrossRef] [PubMed]

5. Paludan-Müller, C.; Dalgaard, P.; Huss, H.H.; Gram, L. Evaluation of the Role of Carnobacterium Piscicola in Spoilage of Vacuumand Modified-Atmosphere-Packed Cold-Smoked Salmon Stored at $5^{\circ}$ C. Int. J. Food Microbiol. 1998, 39, 155-166. [CrossRef]

6. Truelstrup Hansen, L.; Huss, H.H. Comparison of the Microflora Isolated from Spoiled Cold-Smoked Salmon from Three Smokehouses. Food Res. Int. 1998, 31, 703-711. [CrossRef]

7. Jørgensen, L.V.; Dalgaard, P.; Huss, H.H. Multiple Compound Quality Index for Cold-Smoked Salmon (Salmo Salar) Developed by Multivariate Regression of Biogenic Amines and PH. J. Agric. Food Chem. 2000, 48, 2448-2453. [CrossRef]

8. Jørgensen, L.V.; Huss, H.H.; Dalgaard, P. Significance of Volatile Compounds Produced by Spoilage Bacteria in Vacuum-Packed ColdSmoked Salmon (Salmo Salar) Analyzed by GC-MS and Multivariate Regression. J. Agric. Food Chem. 2001, 49, 2376-2381. [CrossRef]

9. Gonzalez-Rodriguez, M.-N.; Sanz, J.-J.; Santos, J.-Á.; Otero, A.; Garcia-Lopez, M.-L. Numbers and Types of Microorganisms in Vacuum-Packed Cold-Smoked Freshwater Fish at the Retail Level. Int. J. Food Microbiol. 2002, 77, 161-168. [CrossRef]

10. Cardinal, M.; Gunnlaugsdottir, H.; Bjoernevik, M.; Ouisse, A.; Luc Vallet, J.; Leroi, F. Sensory Characteristics of Cold-Smoked Atlantic Salmon (Salmo Salar) from European Market and Relationships with Chemical, Physical and Microbiological Measurements. Food Res. Int. 2004, 37, 181-193. [CrossRef]

11. Rachman, C.; Fourrier, A.; Sy, A.; De La Cochetiere, M.F.; Prevost, H.; Dousset, X. Monitoring of Bacterial Evolution and Molecular Identification of Lactic Acid Bacteria in Smoked Salmon during Storage. Le Lait 2004, 84, 145-154. [CrossRef]

12. Olofsson, T.C.; Ahrné, S.; Molin, G. The Bacterial Flora of Vacuum-Packed Cold-Smoked Salmon Stored at $7{ }^{\circ} \mathrm{C}$, Identified by Direct 16S RRNA Gene Analysis and Pure Culture Technique. J. Appl. Microbiol. 2007, 103, 109-119. [CrossRef]

13. Leroi, F. Role of Bacteria in Seafood Products. In Seafood Science: Advances in Chemistry, Technology and Applications; Kim, S.K., Ed.; CRC press: Boca Raton, FL, USA, 2014; pp. 458-482.

14. Leisner, J.J.; Millan, J.C.; Huss, H.H.; Larsen, L.M. Production of Histamine and Tyramine by Lactic Acid Bacteria Isolated from Vacuum-Packed Sugar-Salted Fish. J. Appl. Bacteriol. 1994, 76, 417-423. [CrossRef]

15. Lyhs, U.; Lahtinen, J.; Fredriksson-Ahomaa, M.; Hyytiä-Trees, E.; Elfing, K.; Korkeala, H. Microbiological Quality and Shelf-Life of Vacuum-Packaged 'Gravad' Rainbow Trout Stored at 3 and $8{ }^{\circ} \mathrm{C}$. Int. J. Food Microbiol. 2001, 70, 221-230. [CrossRef]

16. Wiernasz, N.; Leroi, F.; Chevalier, F.; Cornet, J.; Cardinal, M.; Rohloff, J.; Passerini, D.; Skırnisdóttir, S.; Pilet, M.-F. Salmon Gravlax Biopreservation with Lactic Acid Bacteria: A Polyphasic Approach to Assessing the Impact on Organoleptic Properties, Microbial Ecosystem and Volatilome Composition. Front. Microbiol. 2020, 10, 3103. [CrossRef] [PubMed]

17. Chaillou, S.; Chaulot-Talmon, A.; Caekebeke, H.; Cardinal, M.; Christieans, S.; Denis, C.; Hélène Desmonts, M.; Dousset, X.; Feurer, C.; Hamon, E.; et al. Origin and Ecological Selection of Core and Food-Specific Bacterial Communities Associated with Meat and Seafood Spoilage. ISME J. 2015, 9, 1105-1118. [CrossRef] [PubMed]

18. Leroi, F.; Cornet, J.; Chevalier, F.; Cardinal, M.; Coeuret, G.; Chaillou, S.; Joffraud, J.-J. Selection of Bioprotective Cultures for Preventing Cold-Smoked Salmon Spoilage. Int. J. Food Microbiol. 2015, 213, 79-87. [CrossRef]

19. Maillet, A.; Denojean, P.; Bouju-Albert, A.; Scaon, E.; Leuillet, S.; Dousset, X.; Jaffrès, E.; Combrisson, J.; Prévost, H. Characterization of Bacterial Communities of Cold-Smoked Salmon during Storage. Foods 2021, 10, 362. [CrossRef] 
20. Caporaso, J.G.; Lauber, C.L.; Walters, W.A.; Berg-Lyons, D.; Lozupone, C.A.; Turnbaugh, P.J.; Fierer, N.; Knight, R. Global Patterns of 16S RRNA Diversity at a Depth of Millions of Sequences per Sample. Proc. Natl. Acad. Sci. USA 2011, 108, 4516-4522. [CrossRef] [PubMed]

21. Andrews, S. FastQC A Quality Control Tool for High Throughput Sequence Data; BibSonomy: Hessen, Germany, 2010.

22. Hannon, G.J. FASTX-Toolkit 2010. Available online: http://hannonlab.cshl.edu/fastx_toolkit/ (accessed on 18 June 2018).

23. Escudié, F.; Auer, L.; Bernard, M.; Mariadassou, M.; Cauquil, L.; Vidal, K.; Maman, S.; Hernandez-Raquet, G.; Combes, S.; Pascal, G. FROGS: Find, Rapidly, OTUs with Galaxy Solution. Bioinforma. Oxf. Engl. 2018, 34, 1287-1294. [CrossRef]

24. Magoč, T.; Salzberg, S.L. FLASH: Fast Length Adjustment of Short Reads to Improve Genome Assemblies. Bioinforma. Oxf. Engl. 2011, 27, 2957-2963. [CrossRef] [PubMed]

25. Martin, M. Cutadapt Removes Adapter Sequences from High-Throughput Sequencing Reads. EMBnet. J. 2011, 17, 10-12. [CrossRef]

26. Mahé, F.; Rognes, T.; Quince, C.; de Vargas, C.; Dunthorn, M. Swarm: Robust and Fast Clustering Method for Amplicon-Based Studies. Peer] 2014, 2, e593. [CrossRef] [PubMed]

27. Camacho, C.; Coulouris, G.; Avagyan, V.; Ma, N.; Papadopoulos, J.; Bealer, K.; Madden, T.L. BLAST+: Architecture and Applications. BMC Bioinform. 2009, 10, 421. [CrossRef]

28. Quast, C.; Pruesse, E.; Yilmaz, P.; Gerken, J.; Schweer, T.; Yarza, P.; Peplies, J.; Glöckner, F.O. The SILVA Ribosomal RNA Gene Database Project: Improved Data Processing and Web-Based Tools. Nucleic Acids Res. 2013, 41, D590-D596. [CrossRef] [PubMed]

29. R Core Team. R: A Language and Environment for Statistical Computing; R Core Team: Vienna, Austria, 2018.

30. RStudio Team. RStudio: Integrated Development for R; Elsevier: Boston, MA, USA, 2016.

31. McMurdie, P.J.; Holmes, S. Phyloseq: An R Package for Reproducible Interactive Analysis and Graphics of Microbiome Census Data. PLoS ONE 2013, 8, e61217. [CrossRef] [PubMed]

32. Oksanen, J.; Blanchet, F.G.; Friendly, M.; Kindt, R.; Legendre, P.; McGlinn, D.; Minchin, P.R.; O’Hara, R.B.; Simpson, G.L.; Solymos, P.; et al. Vegan: Community Ecology Package, R package version 2.4-6, 2018; ResearchGate: Berlin, Germany, 2019.

33. Love, M.I.; Huber, W.; Anders, S. Moderated Estimation of Fold Change and Dispersion for RNA-Seq Data with DESeq2. Genome Biol. 2014, 15, 550. [CrossRef] [PubMed]

34. Wickham, H. Ggplot2: Elegant Graphics for Data Analysis; Use R! 2nd ed.; Springer International Publishing: Berlin/Heidelberg, Germany, 2016; ISBN 978-3-319-24275-0.

35. ISO 13299. Sensory Analysis, Methodology. General Guidance for Establishing a Sensory Profile; BS ISO 13299:2016: Geneva, Switzerland, 2016.

36. Macé, S.; Joffraud, J.-J.; Cardinal, M.; Malcheva, M.; Cornet, J.; Lalanne, V.; Chevalier, F.; Sérot, T.; Pilet, M.-F.; Dousset, X. Evaluation of the Spoilage Potential of Bacteria Isolated from Spoiled Raw Salmon (Salmo Salar) Fillets Stored under Modified Atmosphere Packaging. Int. J. Food Microbiol. 2013, 160, 227-238. [CrossRef] [PubMed]

37. ISO 8589. Sensory Analysis, General Guidance for the Design of Tests Rooms 2014; BS ISO 8589:2014: Geneva, Switzerland, 2014.

38. Tang, Y.; Horikoshi, M. Ggfortify: Unified Interface to Visualize Statistical Result of Popular R Packages. R J. 2016, 8, 478-489. [CrossRef]

39. Conway, E.J.; Byrne, A. An Absorption Apparatus for the Micro-Determination of Certain Volatile Substances. Biochem. J. 1933, $27,419-429$.

40. Wiernasz, N.; Cornet, J.; Cardinal, M.; Pilet, M.-F.; Passerini, D.; Leroi, F. Lactic Acid Bacteria Selection for Biopreservation as a Part of Hurdle Technology Approach Applied on Seafood. Front. Mar. Sci. 2017, 4-19. [CrossRef]

41. Warnes, G.R.; Bolker, B.; Bonebakker, L.; Gentleman, R.; Huber, W.; Liaw, A.; Lumley, T.; Maechler, M.; Magnusson, A.; Moeller, S.; et al. Gplots: Various R Programming Tools for Plotting Data, R package version 3.0.02016; ResearchGate: Berlin, Germany, 2009.

42. Ghaziri, A.E.; Cariou, V.; Rutledge, D.N.; Qannari, E.M. Analysis of Multiblock Datasets Using ComDim: Overview and Extension to the Analysis of $(\mathrm{K}+1)$ Datasets. J. Chemom. 2016, 30, 420-429. [CrossRef]

43. Tchandao Mangamana, E.; Cariou, V.; Vigneau, E.; Glèlè Kakaï, R.L.; Qannari, E.M. Unsupervised Multiblock Data Analysis: A Unified Approach and Extensions. Chemom. Intell. Lab. Syst. 2019, 194, 103856. [CrossRef]

44. de la Hoz, L.; López-Gálvez, D.E.; Fernández, M.; Hierro, E.; Ordóñez, J.A. Use of Carbon Dioxide Enriched Atmospheres in the Refrigerated Storage $\left({ }^{\circ} \mathrm{C}\right)$ of Salmon (Salmo Salar) Steaks. Eur. Food Res. Technol. 2000, 210, 179-188. [CrossRef]

45. Maqsood, S.; Benjakul, S.; Shahidi, F. Emerging Role of Phenolic Compounds as Natural Food Additives in Fish and Fish Products. Crit. Rev. Food Sci. Nutr. 2013, 53, 162-179. [CrossRef]

46. Leroi, F.; Joffraud, J.J.; Chevalier, F. Effect of Salt and Smoke on the Microbiological Quality of Cold-Smoked Salmon during Storage at 5 Degrees C as Estimated by the Factorial Design Method. J. Food Prot. 2000, 63, 502-508. [CrossRef]

47. Giménez, B.; Dalgaard, P. Modelling and Predicting the Simultaneous Growth of Listeria Monocytogenes and Spoilage MicroOrganisms in Cold-Smoked Salmon. J. Appl. Microbiol. 2004, 96, 96-109. [CrossRef]

48. Porsby, C.H.; Vogel, B.F.; Mohr, M.; Gram, L. Influence of Processing Steps in Cold-Smoked Salmon Production on Survival and Growth of Persistent and Presumed Non-Persistent Listeria Monocytogenes. Int. J. Food Microbiol. 2008, 122, $287-295$. [CrossRef] [PubMed]

49. Hwang, C.-A. The Probability of Growth of Listeria Monocytogenes in Cooked Salmon and Tryptic Soy Broth as Affected by Salt, Smoke Compound, and Storage Temperature. Food Microbiol. 2009, 26, 253-258. [CrossRef] [PubMed]

50. Dalgaard, P.; Gram, L.; Huss, H.H. Spoilage and Shelf-Life of Cod Fillets Packed in Vacuum or Modified Atmospheres. Int. J. Food Microbiol. 1993, 19, 283-294. [CrossRef] 
51. Jørgensen, L.V.; Huss, H.H.; Dalgaard, P. The Effect of Biogenic Amine Production by Single Bacterial Cultures and Metabiosis on Cold-Smoked Salmon. J. Appl. Microbiol. 2000, 89, 920-934. [CrossRef]

52. Fletcher, G.C.; Summers, G.; Corrigan, V.K.; Johanson, M.R.; Hedderley, D. Optimizing Gas Mixtures for Modified Atmosphere Packaging of Fresh King Salmon (Oncorhynchus Tshawytscha). J. Aquat. Food Prod. Technol. 2005, 13, 5-28. [CrossRef]

53. Götz, F.; Bannerman, T.; Schleifer, K.-H. The Genera Staphylococcus and Macrococcus. In The Prokaryotes: Volume 4: Bacteria: Firmicutes, Cyanobacteria; Dworkin, M., Falkow, S., Rosenberg, E., Schleifer, K.-H., Stackebrandt, E., Eds.; Springer: New York, NY, USA, 2006; pp. 5-75, ISBN 978-0-387-30744-2.

54. Slepecky, R.A.; Hemphill, H.E. The Genus Bacillus-Nonmedical. In The Prokaryotes: Volume 4: Bacteria: Firmicutes, Cyanobacteria; Dworkin, M., Falkow, S., Rosenberg, E., Schleifer, K.-H., Stackebrandt, E., Eds.; Springer: New York, NY, USA, 2006; pp. 530-562, ISBN 978-0-387-30744-2.

55. Thapa, N.; Pal, J.; Tamang, J.P. Phenotypic Identification and Technological Properties of Lactic Acid Bacteria Isolated from Traditionally Processed Fish Products of the Eastern Himalayas. Int. J. Food Microbiol. 2006, 107, 33-38. [CrossRef] [PubMed]

56. Andrighetto, C.; Lombardi, A.; Ferrati, M.; Guidi, A.; Corrain, C.; Arcangeli, G. Lactic Acid Bacteria Biodiversity in Italian Marinated Seafood Salad and Their Interactions on the Growth of Listeria Monocytogenes. Food Control 2009, 20, 462-468. [CrossRef]

57. Macé, S.; Cornet, J.; Chevalier, F.; Cardinal, M.; Pilet, M.-F.; Dousset, X.; Joffraud, J.-J. Characterisation of the Spoilage Microbiota in Raw Salmon (Salmo Salar) Steaks Stored under Vacuum or Modified Atmosphere Packaging Combining Conventional Methods and PCR-TTGE. Food Microbiol. 2012, 30, 164-172. [CrossRef] [PubMed]

58. Alfaro, B.; Hernandez, I. Evolution of the Indigenous Microbiota in Modified Atmosphere Packaged Atlantic Horse Mackerel (Trachurus Trachurus) Identified by Conventional and Molecular Methods. Int. J. Food Microbiol. 2013, 167, 117-123. [CrossRef] [PubMed]

59. Sivertsvik, M.; Jeksrud, W.K.; Rosnes, J.T. A Review of Modified Atmosphere Packaging of Fish and Fishery ProductsSignificance of Microbial Growth, Activities and Safety. Int. J. Food Sci. Technol. 2002, 37, 107-127. [CrossRef]

60. Bouletis, A.D.; Arvanitoyannis, I.S.; Hadjichristodoulou, C. Application of Modified Atmosphere Packaging on Aquacultured Fish and Fish Products: A Review. Crit. Rev. Food Sci. Nutr. 2017, 57, 2263-2285. [CrossRef]

61. Silbande, A.; Adenet, S.; Chopin, C.; Cornet, J.; Smith-Ravin, J.; Rochefort, K.; Leroi, F. Effect of Vacuum and Modified Atmosphere Packaging on the Microbiological, Chemical and Sensory Properties of Tropical Red Drum (Sciaenops Ocellatus) Fillets Stored at $4{ }^{\circ}$ C. Int. J. Food Microbiol. 2018, 266, 31-41. [CrossRef]

62. Leroi, F. Occurrence and Role of Lactic Acid Bacteria in Seafood Products. Food Microbiol. 2010, 27, 698-709. [CrossRef]

63. Matamoros, S.; Leroi, F.; Cardinal, M.; Gigout, F.; Kasbi Chadli, F.; Cornet, J.; Prévost, H.; Pilett, M.F. Psychrotrophic Lactic Acid Bacteria Used to Improve the Safety and Quality of Vacuum-Packaged Cooked and Peeled Tropical Shrimp and Cold-Smoked Salmon. J. Food Prot. 2009, 72, 365-374. [CrossRef]

64. Ghanbari, M.; Jami, M.; Domig, K.J.; Kneifel, W. Seafood Biopreservation by Lactic Acid Bacteria-A Review. LWT-Food Sci. Technol. 2013, 54, 315-324. [CrossRef]

65. Stohr, V.; Joffraud, J.J.; Cardinal, M.; Leroi, F. Spoilage Potential and Sensory Profile Associated with Bacteria Isolated from Cold-Smoked Salmon. Food Res. Int. 2001, 34, 797-806. [CrossRef]

66. Joffraud, J.-J.; Cardinal, M.; Cornet, J.; Chasles, J.-S.; Léon, S.; Gigout, F.; Leroi, F. Effect of Bacterial Interactions on the Spoilage of Cold-Smoked Salmon. Int. J. Food Microbiol. 2006, 112, 51-61. [CrossRef]

67. Saraoui, T.; Leroi, F.; Björkroth, J.; Pilet, M.F. Lactococcus Piscium: A Psychrotrophic Lactic Acid Bacterium with Bioprotective or Spoilage Activity in Food-a Review. J. Appl. Microbiol. 2016, 121, 907-918. [CrossRef]

68. Stoddard, S.F.; Smith, B.J.; Hein, R.; Roller, B.R.K.; Schmidt, T.M. RrnDB: Improved Tools for Interpreting RRNA Gene Abundance in Bacteria and Archaea and a New Foundation for Future Development. Nucleic Acids Res. 2015, 43, D593-D598. [CrossRef]

69. Dondero, M.; Cisternas, F.; Carvajal, L.; Simpson, R. Changes in Quality of Vacuum-Packed Cold-Smoked Salmon (Salmo Salar) as a Function of Storage Temperature. Food Chem. 2004, 87, 543-550. [CrossRef]

70. Gram, L.; Huss, H.H. Microbiological Spoilage of Fish and Fish Products. Int. J. Food Microbiol. 1996, 33, 121-137. [CrossRef]

71. Biji, K.B.; Ravishankar, C.N.; Venkateswarlu, R.; Mohan, C.O.; Gopal, T.K.S. Biogenic Amines in Seafood: A Review. J. Food Sci. Technol. 2016, 53, 2210-2218. [CrossRef] [PubMed]

72. de la Torre, C.A.L.; Conte-Junior, C.A. Chapter 6-Detection of Biogenic Amines: Quality and Toxicity Indicators in Food of Animal Origin. In Food Control and Biosecurity; Holban, A.M., Grumezescu, A.M., Eds.; Handbook of Food Bioengineering; Academic Press: Cambridge, MA, USA, 2018; pp. 225-257. ISBN 978-0-12-811445-2.

73. Council Regulation (EC) n ${ }^{\circ}$ 2074/2005 Rules $N^{\circ}$ 2074/2005 of 5 December 2005 Laying down Implementing Measures for Certain Products under Regulation. 2005. Available online: https://eur-lex.europa.eu/legal-content/EN/ALL/?uri=CELEX\%3A32005 R2074 (accessed on 8 October 2018).

74. Masson, F.; Talon, R.; Montel, M.C. Histamine and Tyramine Production by Bacteria from Meat Products. Int. J. Food Microbiol. 1996, 32, 199-207. [CrossRef]

75. Bover-Cid, S.; Holzapfel, W.H. Improved Screening Procedure for Biogenic Amine Production by Lactic Acid Bacteria. Int. J. Food Microbiol. 1999, 53, 33-41. [CrossRef]

76. Olafsdóttir, G.; Jonsdottir, R.; Lauzon, H.L.; Luten, J.; Kristbergsson, K. Characterization of Volatile Compounds in Chilled Cod (Gadus Morhua) Fillets by Gas Chromatography and Detection of Quality Indicators by an Electronic Nose. J. Agric. Food Chem. 2005, 53, 10140-10147. [CrossRef] [PubMed] 
77. Varlet, V.; Knockaert, C.; Prost, C.; Serot, T. Comparison of Odor-Active Volatile Compounds of Fresh and Smoked Salmon. J. Agric. Food Chem. 2006, 54, 3391-3401. [CrossRef] [PubMed]

78. Varlet, V.; Prost, C.; Serot, T. Volatile Aldehydes in Smoked Fish: Analysis Methods, Occurence and Mechanisms of Formation. Food Chem. 2007, 105, 1536-1556. [CrossRef]

79. Jónsdóttir, R.; Ólafsdóttir, G.; Chanie, E.; Haugen, J.-E. Volatile Compounds Suitable for Rapid Detection as Quality Indicators of Cold Smoked Salmon (Salmo Salar). Food Chem. 2008, 109, 184-195. [CrossRef] [PubMed]

80. Joffraud, J.J.; Leroi, F.; Roy, C.; Berdagué, J.L. Characterisation of Volatile Compounds Produced by Bacteria Isolated from the Spoilage Flora of Cold-Smoked Salmon. Int. J. Food Microbiol. 2001, 66, 175-184. [CrossRef]

81. Jaffrès, E.; Lalanne, V.; Macé, S.; Cornet, J.; Cardinal, M.; Sérot, T.; Dousset, X.; Joffraud, J.-J. Sensory Characteristics of Spoilage and Volatile Compounds Associated with Bacteria Isolated from Cooked and Peeled Tropical Shrimps Using SPME-GC-MS Analysis. Int. J. Food Microbiol. 2011, 147, 195-202. [CrossRef] [PubMed]

82. Cardinal, M.; Berdague, J.L.; Dinel, V.; Knockaert, C.; Vallet, J.L. Effect of various smoking techniques on the nature of volatile compounds and on the sensory characteristics of salmon meat. Sci. Aliment. Fr. 1997, 17, 679-696.

83. Guillen, M.D.; Errecalde, M.C.; Salmeron, J.; Casas, C. Headspace Volatile Components of Smoked Swordfish (Xiphias Gladius) and Cod (Gadus Morhua) Detected by Means of Microextraction and Gas Chromatography-Mass Spectrometry. Food Chem. 2006, 94, 151-156. [CrossRef]

84. Wierckx, N.; Koopman, F.; Ruijssenaars, H.J.; de Winde, J.H. Microbial Degradation of Furanic Compounds: Biochemistry, Genetics, and Impact. Appl. Microbiol. Biotechnol. 2011, 92, 1095-1105. [CrossRef]

85. Park, S.-K.; Kim, M.-S.; Jung, M.-J.; Nam, Y.-D.; Park, E.-J.; Roh, S.W.; Bae, J.-W. Brachybacterium Squillarum Sp. Nov., Isolated from Salt-Fermented Seafood. Int. J. Syst. Evol. Microbiol. 2011, 61, 1118-1122. [CrossRef]

86. Liu, Y.; Xie, Q.-Y.; Shi, W.; Li, L.; An, J.-Y.; Zhao, Y.-M.; Hong, K. Brachybacterium Huguangmaarense Sp. Nov., Isolated from Lake Sediment. Int. J. Syst. Evol. Microbiol. 2014, 64, 1673-1678. [CrossRef]

87. Kaur, G.; Kumar, N.; Mual, P.; Kumar, A.; Kumar, R.M.; Mayilraj, S. Brachybacterium Aquaticum Sp. Nov., a Novel Actinobacterium Isolated from Seawater. Int. J. Syst. Evol. Microbiol. 2016, 66, 4705-4710. [CrossRef] [PubMed]

88. Tak, E.J.; Kim, P.S.; Hyun, D.-W.; Kim, H.S.; Lee, J.-Y.; Kang, W.; Sung, H.; Shin, N.-R.; Kim, M.-S.; Whon, T.W.; et al. Phenotypic and Genomic Properties of Brachybacterium Vulturis Sp. Nov. and Brachybacterium Avium Sp. Nov. Front. Microbiol. 2018, 9-20. [CrossRef]

89. Aranda, S.; Montes-Borrego, M.; Landa, B.B. Purple-Pigmented Violacein-Producing Duganella Spp. Inhabit the Rhizosphere of Wild and Cultivated Olives in Southern Spain. Microb. Ecol. 2011, 62, 446-459. [CrossRef] [PubMed]

90. Madhaiyan, M.; Poonguzhali, S.; Saravanan, V.S.; Hari, K.; Lee, K.-C.; Lee, J.-S. Duganella Sacchari Sp. Nov. and Duganella Radicis Sp. Nov., Two Novel Species Isolated from Rhizosphere of Field-Grown Sugar Cane. Int. J. Syst. Evol. Microbiol. 2013, 63, 1126-1131. [CrossRef] [PubMed]

91. Haack, F.S.; Poehlein, A.; Kröger, C.; Voigt, C.A.; Piepenbring, M.; Bode, H.B.; Daniel, R.; Schäfer, W.; Streit, W.R. Molecular Keys to the Janthinobacterium and Duganella Spp. Interaction with the Plant Pathogen Fusarium Graminearum. Front. Microbiol. 2016, 7, 1668. [CrossRef]

92. An, S.-Y.; Asahara, M.; Goto, K.; Kasai, H.; Yokota, A. Terribacillus Saccharophilus Gen. Nov., Sp. Nov. and Terribacillus Halophilus Sp. Nov., Spore-Forming Bacteria Isolated from Field Soil in Japan. Int. J. Syst. Evol. Microbiol. 2007, 57, 51-55. [CrossRef] [PubMed]

93. Liu, W.; Jiang, L.; Guo, C.; Yang, S.S. Terribacillus Aidingensis Sp. Nov., a Moderately Halophilic Bacterium. Int. J. Syst. Evol. Microbiol. 2010, 60, 2940-2945. [CrossRef]

94. Lu, P.; Lei, M.; Xiao, F.; Zhang, L.; Wang, Y. Complete Genome Sequence of Terribacillus Aidingensis Strain MP602, a Moderately Halophilic Bacterium Isolated from Cryptomeria Fortunei in Tianmu Mountain in China. Genome Announc. 2015, 3, e0012-15. [CrossRef]

95. Lee, S.D. Spelaeicoccus Albus Gen. Nov., Sp. Nov., an Actinobacterium Isolated from a Natural Cave. Int. J. Syst. Evol. Microbiol. 2013, 63, 3958-3963. [CrossRef]

96. Rattray, F.P.; Fox, P.F. Aspects of Enzymology and Biochemical Properties of Brevibacterium Linens Relevant to Cheese Ripening: A Review. J. Dairy Sci. 1999, 82, 891-909. [CrossRef]

97. Onraedt, A.; Soetaert, W.; Vandamme, E. Industrial Importance of the Genus Brevibacterium. Biotechnol. Lett. 2005, 27, 527-533. [CrossRef]

98. Srilekha, V.; Krishna, G.; Seshasrinivas, V.; Charya, M.A.S. Antibacterial and Anti-Inflammatory Activities of Marine Brevibacterium Sp. Res. Pharm. Sci. 2017, 12, 283-289. [CrossRef] [PubMed]

99. Choi, K.D.; Siddiqi, M.Z.; Liu, Q.; Muhammad Shafi, S.; Durrani, Y.; Lee, S.Y.; Kang, M.-S.; Im, W.T. Brevibacterium Hankyongi Sp. Nov., Isolated from Compost. Int. J. Syst. Evol. Microbiol. 2018, 68, 2783-2788. [CrossRef] [PubMed]

100. Valles, C.; Fournier, P.-E.; Raoult, D.; Cadoret, F. "Brevibacterium Ihuae" Sp. Nov., Isolated from a Stool Sample of a Healthy 25-Year-Old Woman. New Microbes New Infect. 2018, 21, 49-50. [CrossRef] [PubMed]

101. Wauters, G.; De Baere, T.; Willems, A.; Falsen, E.; Vaneechoutte, M. Description of Comamonas Aquatica Comb. Nov. and Comamonas Kerstersii Sp. Nov. for Two Subgroups of Comamonas Terrigena and Emended Description of Comamonas Terrigena. Int. J. Syst. Evol. Microbiol. 2003, 53, 859-862. [CrossRef] [PubMed]

102. Sun, L.-N.; Zhang, J.; Chen, Q.; He, J.; Li, Q.-F.; Li, S.-P. Comamonas Jiangduensis Sp. Nov., a Biosurfactant-Producing Bacterium Isolated from Agricultural Soil. Int. J. Syst. Evol. Microbiol. 2013, 63, 2168-2173. [CrossRef] [PubMed]

103. Zhu, D.; Xie, C.; Huang, Y.; Sun, J.; Zhang, W. Description of Comamonas Serinivorans Sp. Nov., Isolated from Wheat Straw Compost. Int. J. Syst. Evol. Microbiol. 2014, 64, 4141-4146. [CrossRef] 
104. Dai, W.; Zhu, Y.; Wang, X.; Sakenova, N.; Yang, Z.; Wang, H.; Li, G.; He, J.; Huang, D.; Cai, Y.; et al. Draft Genome Sequence of the Bacterium Comamonas Aquatica CJG. Genome Announc. 2016, 4, e01186-16. [CrossRef]

105. Kang, W.; Soo Kim, P.; Hyun, D.-W.; Lee, J.-Y.; Sik Kim, H.; Joon Oh, S.; Shin, N.-R.; Bae, J.-W. Comamonas Piscis Sp. Nov., Isolated from the Intestine of a Korean Rockfish, Sebastes Schlegelii. Int. J. Syst. Evol. Microbiol. 2016, 66, 780-785. [CrossRef]

106. Veress, A.; Wilk, T.; Kiss, J.; Papp, P.P.; Olasz, F. Two Draft Genome Sequences of Sphingobacterium Sp. Strains Isolated from Honey. Genome Announc. 2017, 5, e01364-17. [CrossRef]

107. Chatterjee, S.; Mukhopadhyay, S.K.; Gauri, S.S.; Dey, S. Sphingobactan, a New $\alpha$-Mannan Exopolysaccharide from Arctic Sphingobacterium Sp. IITKGP-BTPF3 Capable of Biological Response Modification. Int. Immunopharmacol. 2018, 60, 84-95. [CrossRef] [PubMed]

108. Chaudhary, D.K.; Kim, J. Sphingobacterium Terrae Sp. Nov., Isolated from Oil-Contaminated Soil. Int. J. Syst. Evol. Microbiol. 2018, 68, 609-615. [CrossRef]

109. Kaur, M.; Singh, H.; Sharma, S.; Mishra, S.; Tanuku, N.R.S.; Pinnaka, A.K. Sphingobacterium Bovisgrunnientis Sp. Nov., Isolated from Yak Milk. Int. J. Syst. Evol. Microbiol. 2018, 68, 636-642. [CrossRef]

110. Niu, X.; Cui, W.; Cui, M.; Zhang, X.; Zhang, S.; Xu, B.; Gao, M. Sphingobacterium Solani Sp. Nov., Isolated from Potato Stems. Int. J. Syst. Evol. Microbiol. 2018, 68, 1012-1017. [CrossRef] [PubMed]

111. Sharma, S.; Chatterjee, S. Psychrotolerant Sphingobacterium Kitahiroshimense LT-2 Isolated from Dhundi Glacier, Himachal Pradesh: Origin Prediction and Future Application. Indian J. Microbiol. 2018, 58, 234-238. [CrossRef]

112. Van Le, V.; Padakandla, S.R.; Kim, H.; Chae, J.-C. Sphingobacterium Praediipecoris Sp. Nov. Isolated from Effluent of a Dairy Manure Treatment Plant. Arch. Microbiol. 2018, 200, 1481-1486. [CrossRef]

113. Yim, K.J.; Cha, I.-T.; Lee, H.-W.; Song, H.S.; Kim, K.-N.; Lee, S.-J.; Nam, Y.-D.; Hyun, D.-W.; Bae, J.-W.; Rhee, S.-K.; et al. Halorubrum Halophilum Sp. Nov., an Extremely Halophilic Archaeon Isolated from a Salt-Fermented Seafood. Antonie Van Leeuwenhoek 2014, 105, 603-612. [CrossRef]

114. Corral, P.; de la Haba, R.R.; Sánchez-Porro, C.; Amoozegar, M.A.; Papke, R.T.; Ventosa, A. Halorubrum Persicum Sp. Nov., an Extremely Halophilic Archaeon Isolated from Sediment of a Hypersaline Lake. Int. J. Syst. Evol. Microbiol. 2015, 65, 1770-1778. [CrossRef] [PubMed]

115. Kondo, Y.; Minegishi, H.; Echigo, A.; Shimane, Y.; Kamekura, M.; Itoh, T.; Ohkuma, M.; Takahashi-Ando, N.; Fukushima, Y.; Yoshida, Y.; et al. Halorubrum Gandharaense Sp. Nov., an Alkaliphilic Haloarchaeon from Commercial Rock Salt. Int. J. Syst. Evol. Microbiol. 2015, 65, 2345-2350. [CrossRef]

116. Sánchez-Nieves, R.; Facciotti, M.T.; Saavedra-Collado, S.; Dávila-Santiago, L.; Rodríguez-Carrero, R.; Montalvo-Rodríguez, R. Draft Genome Sequence of Halorubrum Tropicale Strain V5, a Novel Halophilic Archaeon Isolated from the Solar Salterns of Cabo Rojo, Puerto Rico. Genom. Data 2016, 7, 284-286. [CrossRef]

117. Mou, Y.-Z.; Qiu, X.-X.; Zhao, M.-L.; Cui, H.-L.; Oh, D.; Dyall-Smith, M.L. Halohasta Litorea Gen. Nov. Sp. Nov., and Halohasta Litchfieldiae Sp. Nov., Isolated from the Daliang Aquaculture Farm, China and from Deep Lake, Antarctica, Respectively. Extrem. Life Extrem. Cond. 2012, 16, 895-901. [CrossRef] [PubMed] 